\title{
Molecular cytogenetic characterization of natural hybrids of Roegneria stricta and Roegneria turczaninovii (Triticeae: Poaceae)
}

Chen Chen ${ }^{1}$, Lue Zheng ${ }^{1}$, Dan $\mathrm{Wu}^{1}$, Lu Tan ${ }^{1}$, Rong Yang ${ }^{2}$, Qing Liu ${ }^{2}$, Le Lu ${ }^{3}$, Xing Fan ${ }^{1}$, Lina Sha ${ }^{3}$, Houyang Kang ${ }^{1}$, Yi Wang ${ }^{1}$, Hong Zhou $^{1}$, Bing Zhang ${ }^{4}$, and Haiqin Zhang ${ }^{3}$

${ }^{1}$ Triticeae Research Institute

${ }^{2}$ College of Chemistry and Life Sciences

${ }^{3}$ College of Grassland Science and Technology

${ }^{4}$ Sichuan Academy of Grassland Science

May 11, 2021

\begin{abstract}
Hybridization is an important part of species evolution. The hybrid progeny population had rich genetic and phenotypic variation, which made the boundaries between them and their parents blurred and difficult to distinguish. There was little research on the origin of natural hybrids of Triticeae. In this study, we found a large number of putative hybrids of Roegneria in West Sichuan Plateau, China. The hybrid plants showed strong heterosis in plant height, tiller number and floret number. Morphologically, the putative hybrids showed intermediate of Roegneria stricta Keng and Roegneria turczaninovii (Drob.) Nevski. Hybrids had 28 chromosomes corresponding to that of R. stricta and R. turczaninovii $(2 \mathrm{n}=4 \mathrm{x}=28)$. Meiotic pairing in hybrids were less regular than those of R. stricta and R. turczaninovii. GISH analysis showed that the hybrid plants had the same genome as that of R. stricta and R. turczaninovii (StY). Phylogenetic analysis based on the single copy nuclear gene DMC1 and chloroplast gene rps16 showed the plants were closely related to R. stricta and R. turczaninovii. This study indicated that the plants were hybrids of R. stricta and R. turczaninovii. The results provided data for the utilization of hybrid. This study provided a case study of natural hybrids.
\end{abstract}

\section{Molecularcytogenetic characterization of natural hybrids of Roegneria} stricta and Roegneria turczaninovii (Triticeae: Poaceae)

Chen Chen ${ }^{2 \#}$, Zilue Zheng ${ }^{2 \#}$, Dandan $\mathrm{Wu}^{2},{ }^{5}, \mathrm{Lu} \mathrm{Tan}^{2}$, Cairong Yang ${ }^{4}$, Songqing Liu ${ }^{4}$, Jiale $\mathrm{Lu}^{1,5}$, Xing $\mathrm{Fan}^{2,5}$, Lina Sha ${ }^{2,5}$, Houyang Kang ${ }^{2,5}$, Yi Wang ${ }^{2,5}$, Yonghong Zhou ${ }^{2}$, , Changbing Zhang ${ }^{*}$, Haiqin Zhang ${ }^{1,5 *}$

${ }^{1}$ College of Grassland Science and Technology, Sichuan Agricultural University, Chengdu 611130, Sichuan, China;

2 Triticeae Research Institute, Sichuan Agricultural University, Chengdu 611130, Sichuan, China;

${ }^{3}$ Sichuan Academy of Grassland Science, Chengdu 610000, Sichuan, China;

${ }^{4}$ College of Chemistry and Life Sciences, Chengdu Normal University, Chengdu 611130, Sichuan, China;

${ }^{5}$ State Key Laboratory of Crop Gene Exploration and Utilization in Southwest China,Sichuan Agricultural University, Chengdu 611130, Sichuan, China . 
*Corresponding author. E-mail:haiqinzhang@163.com (HQ. Zhang),c.b.zhang@126.com(CB. Zhang)

Abstract Hybridization is an important part of species evolution. The hybrid progeny population had rich genetic and phenotypic variation, which made the boundaries between them and their parents blurred and difficult to distinguish. There was little research on the origin of natural hybrids of Triticeae. In this study, we found a large number of putative hybrids of Roegneria in West Sichuan Plateau, China. The hybrid plants showed strong heterosis in plant height, tiller number and floret number. Morphologically, the putative hybrids showed intermediate of Roegneria stricta Keng and Roegneriaturczaninovii (Drob.) Nevski. Hybrids had 28 chromosomes corresponding to that of $R$. stricta and $R$. $t u$ rczaninovii $(2 \mathrm{n}=4 \mathrm{x}=28)$. Meiotic pairing in hybrids were less regular than those of $R$. stricta and $R$. turczaninovii. GISH analysis showed that the hybrid plants had the same genome as that of $R$. stricta and $R$. turczaninovii(StY ). Phylogenetic analysis based on the single copy nuclear gene $D M C 1$ and chloroplast gene rps 16 showed the plants were closely related to $R$. stricta and $R$. turczaninovii. This study indicated that the plants were hybrids of $R$. strictaand $R$. turczaninovi $\mathrm{i}$. The results provided data for the utilization of hybrid. This study provided a case study of natural hybrids.

KEYWORDS Natural hybrids, GISH, phylogenetic analysis, Roegneria, genome, meiotic pairing.

Cover letter

Dear editor,

The submitted is the following manuscript for your consideration to Ecology and Evolution: "Molecular cytogenetic characterization of natural hybrids of Roegneria stricta andRoegneria turczaninovii (Triticeae: Poaceae) ", by Chen Chen, Zi-Lue Zheng, Dan-Dan Wu, Tan Lu, Cai-Rong Yang, Song-Qing Liu, Jia-Le Lu, Yong-Hong Zhou, Chang-Bing Zhang, Hai-Qin Zhang.

In the present study, to explore the origin and formation mechanism of natural hybrids, we performed morphological analysis, Karyotype analysis, chromosome pairing analysis, genomic in situhybridization and phylogenetic analyses. The results confirmed that natural hybrids showed strong heterosis in plant height, tiller number and floret number. Morphologically, the hybrids showed intermediate of Roegneria stricta Keng and Roegneria turczaninovii (Drob.) Nevski. Meiotic pairing in hybrids were less regular than those of $R$. stricta and $R$. turczaninovii. GISH analysis showed that the hybrid plants had the same genome as that of $R$. stricta and $R$. turczaninovii (StY ). Phylogenetic analysis based on the single copy nuclear gene DMC 1 and chloroplast generps 16 showed the plants were closely related to $R$. strictaand $R$. turczaninovii . This study indicated that the plants were hybrids of $R$. stricta and $R$. turczaninovii .

The work described has not been submitted elsewhere for publication, in whole or in part, and all authors listed have approved the manuscript that enclosed.

We hope that you will kindly consider this submission for publication.

If you have any questions, please contact me freely.

Sincerely,

Haiqin Zhang

College of Grassland Science and Technology,

Sichuan Agricultural University,

Wenjiang 611130,

China

haiqinzhang@163.com; Tel: +86 13550042478

1 | INTRODUCTION 
The tribe Triticeae (Poaceae) represented an important gene pool for genetic improvement of cereal crops and forage grasses. It included approximately 450 species that distributed in a wide range of ecological habitats over the temperate and subtropical and tropic alpine regions (Dewey, 1984). The majority of species in Triticeae were allopolyploids, with ploidy levels ranging from diploid $(2 \mathrm{n}=2 \mathrm{x})$ to dodecaploid $(2 \mathrm{n}=12 \mathrm{x})$. Natural hybridization between different genera or species oftenoccurred in the Triticeae. As early as 1926, the natural hybrid of Triticum - Aegilops - Secale was reported (Von Tschermak \& Bleier, 1926). Stebbins et al. reported a series of natural hybrids in the Triticeae: natural hybrids of E. condensatus and $E$. triticoides (Stebbins \& Walters, 1949); triploid hybrids of Agropyron and Elymus (Stebbins \& Singh, 1950); natural hybrids of Elymus and Sitanion (Stebbins \& Vaarama, 1954). At the same time, they performed artificial hybridization, artificial and natural hybrids for morphology, chromosome pairing, seed set and other aspects of comparison, speculated that the possible origin of natural hybrids (Stebbins \& Walters, 1949; Stebbins \& Singh, 1950; Stebbins \& Vaarama, 1954).

Roegneria C. Koch was a relatively large perennial genus in Triticeae, and includes approximately 130 species, most of which were tetraploid with StY -genome, nearly 70 of which were found in China (Yang et al., 2008). Roegneria species not only provided genetic material for the improvement of forage crops but could also be used as potential contributors of genes for cereal crops (Keng, 1959). Predecessors have reported some studies on the hybrids of Roegneria, such as a hybrid of Roegneria and Hordeum (Zhou et al., 1995), a hybrid of R. ciliaris and Leymus multicaulis (Zhang et al., 2008). These hybrids were created by the artificial hybridization and could not replace the value of natural hybrids. In recent years, researchers had discovered some natural hybrids of Roegneria. For example, Zeng et al. (2012) had discovered the pentaploid natural hybrids (StStYYP ) between Roegneria (StY) andKengyilia (StYP).

In the process of plant system evolution, hybridization was the direct cause of the formation of diploid and polyploid species and the production of reticulate evolution (Rieseberg, 1995; Soltis \& Soltis, 1993). However, it was not easy to accurately identify whether a species was a hybrid and to explore origin of hybrids (Rauscher et al., 2002). Early identification of hybridization was mainly based on morphological characteristics, and it was often based on the morphology intermediate of the parents to infer whether a plant came from a hybridization. However, the reliability of morphological markers was low, and morphology intermediate was not always related to hybridization. It may also be caused by convergent evolution or environment. Therefore, morphological markers could not be used alone to identify hybrids (Rieseberg, 1995). Cytological markers have been used as important criteria for hybridization, including karyotype analysis, meiotic pairing analysis, Genomic in situ hybridization (GISH) and Fluorescence in situ hybridization (FISH), which could be used to identify and analyze natural hybrids (Han et al., 2004; Mao et al., 2017). For example, Using FISH and GISH techniques, the two parents ofElytrigia $\times$ mucronata could be studied through signal sites on chromosomes (Paštová et al., 2019). However, due to the high parental chromosome homology of interspecific hybrids, it was difficult to explore origin of hybrids by FISH and GISH. Therefore, even if a species has been determined from morphology or cytogenetics to be a hybrid or hybrid origin, it still needs to be verified with some other evidence (Soltis et al., 1992). Phylogenetic analysis could not only reflect the genetic relationship between hybrids and parents, but also overcome the shortcomings of non-dominance and insufficient repetitiveness of other molecular markers. The method was also the first choice for identifying natural hybrids (Quijada et al., 1997; Sang et al., 1995). Since genes at different sites in the genome of diploid or polyploid hybrids derived from different parent species, these genes have different evolutionary processes. This was the basis for detecting hybridization by phylogenetic analysis (Yu et al., 2011). Single- or low-copy nuclear genes, which were less susceptible to concerted evolution, could serve as useful markers for studies of phylogenetic relationships (Lei et al., 2018; Sha et al., 2010). Among the available nuclear sequences, DNA meiotic recombinase 1 ( $D M C$ 1) gene sequences have been used to examine hybridization events (Tang et al., 2017). The chloroplast DNA (cp DNA) is maternally inherited in grasses (Smith et al., 2006). Among the available chloroplast sequences, ribosomal protein S16 (rps 16) were used to identify the maternal donor of genera in Triticeae (Yan et al., 2014).

The experimental field of Sichuan Academy of Grassland Science (SAGS) located on Northwest Sichuan Plateau, China (Hongyuan county, Sichuan Province, 31 51' to 33deg33' N, 101deg51' to 103deg22' W) 
at altitude $3500 \mathrm{~m}$. Two species ofRoegneria [Roegneria stricta Keng and Roegneriaturczaninovii (Drob.) Nevski] were planted very close in SAGS. We harvested the seeds of the two species and then individual planting. After three years growing, we found that 23 putative hybrids $(5.75 \%, 23 / 400)$ randomly distributed in $R$. stricta field and 54 putative hybrids $(16.36 \%, 54 / 330)$ randomly distributed in $R$. turczaninovii field (Figures 2 a-c). These putative hybrids grew stronger than around plants and their seed set was very low (0.23\%-5.59\%, Figure 3). They showed intermediate morphological characters of $R$. stricta and $R$. turczaninovii, such as pubescence of leaf, basal leaf sheath and stem node (Figures 1 d-o).

Both of $R$. stricta and $R$. turczaninovii were tetraploid perennial species $(2 \mathrm{n}=4 \mathrm{x}=28)$ with the $\mathbf{S t Y}$ genome. $R$. stricta come from Luhuo County, Sichuan, China while $R$. turczaninovii origins from Linxi County, Inner Mongolia, China. Because these two species had the same ploidy and genome constitutions, natural hybridizations might occur between them if they were grown together for a long time. In the current study, we hypothesized that the sterile plants were hybrids of $R$. stricta and $R$. turczaninovii . To determine if this is indeed the case, we conducted different methods including morphological analysis, fertility analysis, karyotype, meiotic pairing analysis, in situ hybridization and DNA sequence analysis in these putative hybrids and their accompanying plants. The results provided useful resources for origin and formation mechanism of natural hybrids, species evolution in the Triticeae, and laid material foundation for breeding new varieties.

\section{2 | METHODS AND MATERIALS}

\section{1 | Plant materials}

57 putative nature hybrids including 17 hybrids (named RH1) found in $R$. stricta field and 40 hybrids (named RH2) appeared in $R$. turczaninovii field were used in this study (Table 1). The possible parents $R$. stricta and $R$. turczaninovii, and the other Triticeae species growing nearby were also obtained, including species of Roegneria and Elymus. All of them were collected from the experimental field of SAGS, Hongyuan County, Sichuan, China. 20 diploid species (representing the genomes $\mathbf{S t}, \mathbf{H}, \mathbf{E}^{\mathbf{e}}, \mathbf{E}^{\mathbf{b}}, \mathbf{W}, \mathbf{P}, \mathbf{T a}, \mathbf{V}, \mathbf{N s}, \mathbf{A}, \mathbf{B}$ , and $\mathbf{D}$ ), and species with different genomic combinations ( $\mathbf{S t Y}, \mathbf{S t H}$ ) from the tribe Triticeae were used for DNA sequences analysis. The names of the sampled taxa, abbreviations, accession numbers, ploidy level, genomic constitution and GenBank accession numbers were listed in Table S1. Materials with PI and $\mathrm{W}_{6}$ were kindly provided by American National Plant Germplasm System (Pullman, WA, USA). The authors of the present study collected all other accessions, for which voucher specimens were deposited with the perennial nursery and herbarium of the Triticeae Research Institute, Sichuan Agricultural University, China (SAUTI).

\section{2 | Morphological analysis}

Morphological analysis was performed on $R$. stricta , R. turczaninovii and putative hybrids. Agronomic traits were observed including plant height, tiller number, floret number, length of flag leaves, width of flag leaves, length of spikes, etc. Each trait was measured 10 times and the average was calculated. The pubescence of leaf, basal leaf sheath and stem node were recorded by direct observation.

\section{3 | Pollen fertility and seed set}

The pollens grains from mature anthers were stained in an $\mathrm{I}_{2}-\mathrm{KI}$ solution for pollen fertility study. Seed set was estimated from a 10 -spike sample per plant.

\subsection{Karyotype and meiotic pairing analysis}

Karyotype analysis were followed by Gill et al. (1991). The procedures of fixation, staining and calculation of meiotic pairing followed Zhang and Zhou (2006).

\section{5 | Chromosome preparation and in situhybridization}

Chromosomes were prepared for GISH analysis according to the method of Han et al. (2004). Total genomic DNA was extracted from fresh leaves by the CTAB method (Murray \& Thompson, 1980). Plasmids (from 
positive clones that are $\mathbf{S t}$ genome) and the StY genome were labeled with fluorescein-12-dUTP or Texasred-5-dCTP using the nick translation method. Hybridization procedure, detection, and visualization were performed according to the method of Wang et al (2017).

\section{6 | Amplification and sequencing}

The DMC 1 and rps 16 gene was amplified using the primers listed in Table S1 (Petersen \& Seberg 2002; Shaw et al., 2005). All PCRs were conducted in a 50- $\mu \mathrm{L}$ reaction volume, with $1.5 \mathrm{U}$ ExTaq polymerase (TaKaRa, Shiga, Japan). The PCR amplification protocols for the DMC 1 and rps 16 gene are presented in Table S1. PCR products were cloned into the pMD19-T vector (TaKaRa). At least 15 random independent clones were selected for sequencing by Shanghai Sangon Biological Engineering and Technology Service Ltd. (Shanghai, China).

\section{7 | Data analysis}

The phylogenetic analyses of DMC 1 and rps 16 data by using the maximum-likelihood (ML) method in PhyML 3.0 (Guindon et al., 2009). The best-fit evolutionary model for phylogenetic analysis was determined using ModelTest v3.7 with Akaike information criterion (Posada \& Crandall, 1998). As a measurement of the robustness of tree clades, the bootstrap support (BS) values were calculated with 1000 replications and displayed in figure (above the branch) if the BS values were $>50 \%$ (Felsenstein, 1985).

In addition to ML analysis, Bayesian analyses were also performed using MrBayes 3.1 (Ronquist \& Huelsenbeck, 2003). The evolutionary model selected for Bayesian analyses was same as ML analysis.

\section{3 | RESULTS}

\section{1 | Morphological characteristics}

The 57 putative natural hybrids were perennial grasses, which were similar in morphology and phenology to Roegneria species, such as one spikelet per node and palea equaling lemma. Most of hybrids were stronger than their surrounding plants (Figures 1a-c). These natural hybrids combined some unique characteristics of $R$. stricta and $R$. turczaninovii, such as leaf pubescence, stem node pubescence and basal leaf sheath pubescence (Figures 1d-o).

The height of hybrids RH1 $(128.90 \pm 1.27 \mathrm{~cm})$ and hybrids RH2 $(132.68 \pm 1.86 \mathrm{~cm})$ was higher than that of $R$. turczaninovii $(118.63 \pm 1.11 \mathrm{~cm})$ and $R$. stricta $(118.70 \pm 1.54 \mathrm{~cm})$ (Figure 2a). Hybrids RH1 (284.18 $\pm 12.24)$ and hybrids RH2 (389.63 \pm 13.72$)$ showed more tillers than $R$. turczaninovii $(112.00 \pm 9.72)$ and $R$. stricta $(225.93 \pm 15.35)$ (Figure $2 \mathrm{~b})$. The hybrids showed intermediate character between $R$. stricta and $R$. turczaninovii in the length of flag leaves, width of flag leaves, length of top second leaf, width of top second leaf, length of awn, and length of the spike (Figures 2c-2g, 2i).

\subsection{Evaluation of pollen fertility and seed set}

The fertility, including pollen fertility and seed set, of $R$. stricta, $R$. turczaninovii and putative hybrids were shown in Figure 3. In R. stricta, the pollen fertilities were up to $92.05 \%$ and the seed sets were $90.02 \%$. In R. turczaninovii, the pollen fertilities and seed set were high with $91.61 \%$ and $92.18 \%$, respectively.

As for the hybrids RH1, the pollen fertilities varied from $1.01 \%-8.09 \%$, and the seed sets were lower than those of their possible parents, varying from $0.41 \%-4.50 \%$ (Figure 3). As for the hybrids RH2, the pollen fertilities varied from $0.83 \%-13.63 \%$, and seed set were lower, varying from $0.23 \%-5.59 \%$ (Figure 3 ). It could be seen that the pollen fertilities and seed sets of putative hybrids were very low, indicating that they were hybrids and not stable species.

\section{3 | Karyotype analysis and chromosome pairing at metaphase I}

Karyotype analysis showed that $R$. stricta,$R$. turczaninovii and putative hybrids were tetraploids $(2 \mathrm{n}=$ $4 \mathrm{x}=28)($ Figure 4$)$. The meiotic configurations of the possible parent and the putative hybrids were listed in Table S2. 
Meiosis of $R$. stricta and $R$. turczaninovii were quite regular with 14 bivalents (Figures 5a-c, Table S2). Meiotic pairing in 17 hybrids RH1 were comparatively high, with an average of 0.98 univalents and 13.52 bivalents per cell with c-value of 0.89 (Figures 5d, e; Table S2). Chromosome pairing in 40 hybrids RH2 were comparatively high with an average of 0.85 univalents and 13.55 bivalents per cell with c-value of 0.90 (Figures 5g, h; Table S2). Except for hybrid RH2-31, all hybrids had univalent. In all hybrids, the c-value was higher than 0.81 , suggesting that chromosome pairing of the hybrids was comparatively regular and two sets of genomes in hybrids were homology.

At the same time, some lagging chromosomes and chromosome bridges were observed at anaphase I. (Figures $5 f, \mathrm{i})$.

\section{4 | FISH and GISH analysis}

To further explore the genomic constitutions of natural hybrids, we selected some hybrids for in situ hybridization. $\mathrm{St}_{2}-80$ was a FISH marker for the $\mathbf{S t}$ genome (Wang, et al., 2017). Signals produced by $\mathrm{St}_{2}-80$ were present on the entire arm of the $\mathbf{S t}$ genome chromosomes, except at the centromeric region and near centromeric region (Wang et al., 2017). This marker was used to detect if the St genome presented in the putative parents and hybrids.

FISH results showed that 14 chromosomes of putative parents and hybrids displayed fluorescent signals indicating that they contained one set of St genome (Figures 6a, c, e and 7a, c, e). This result was confirmed by GISH analysis, where 28 chromosomes of putative parents and hybrids were hybridized with theStY probe from $R$. ciliaris (Figures $6 \mathrm{~b}, \mathrm{~d}, \mathrm{f}$ and $7 \mathrm{~b}, \mathrm{~d}, \mathrm{f}$ ). The results of FISH and GISH indicated that the genomic constitution of putative parents and 11 hybrids (RH1-3, RH1-8, RH1-11, RH1-14, RH2-2, RH2-10, RH2-12, RH2-15, RH2-17, RH2-37, RH2-39) were StY .

\subsection{Phylogenetic analyses of the nuclear gene $D M C 1$ and the chloroplast gene rps 16 sequences}

In order to analyze the possible parents of the hybrids, we analyzed the nuclear gene $D M C 1$ and the chloroplast gene rps 16 sequences of the hybrids and their associated species of Roegneria andElymus. The length of $D M C 1$ sequences of hybrids ranged from 998 to $1004 \mathrm{bp}$. The data matrix contained 1166 characters, of which 267 characters were variable and 235 were parsimony informative. A single phylogenetic tree generating by maximum likelihood analysis using the TPM1uf $+\mathrm{G}$ model (-Ln likelihood $=4547.37)$ was shown in Figure 8. The phylogenetic analyses of the $D M C 1$ sequence were shown in Figure 8. In clade I (BS=54\%, $\mathrm{PP}=0.97$ ), the $\mathbf{S t}$-type sequences formed a strongly supported clade, which included diploidPseudoroegneria (St) species, tetraploid Elymus $(\mathbf{S t H})$ and Roegneria (StY) species and hybrids. The St-type sequences of 15 hybrids and $R$. turczaninovii $(\mathbf{S t Y})$ formed a subclade $(\mathrm{BS}=51 \%, \mathrm{PP}=1.00)$. In clade II (BS=99\%, $\mathrm{PP}=1.00)$, the $\mathbf{Y}$-type sequences formed a strongly supported clade, which contained the tetraploid species ofRoegneria (StY) species and hybrids. The $\mathbf{Y}$-type sequences of 15 hybrids, $R$. turczaninovii (StY) and $R$. stricta $(\mathbf{S t Y})$ formed a subclade $(\mathrm{BS}=64 \%, \mathrm{PP}=0.83)$. In clade III $(\mathrm{BS}=96 \%, \mathrm{PP}=1.00)$, the H-type subclade included diploid Hordeum species and tetraploid Elymus $(\mathbf{S t H})$ species. Clade IV (BS=96\%, PP=1.00). other clade included 10 diploid species containing 10 different basic genomes $\left(\mathbf{E}^{\mathbf{e}}, \mathbf{E}^{\mathbf{b}}, \mathbf{W}, \mathbf{P}, \mathbf{T a}, \mathbf{V}, \mathbf{N s}, \mathbf{A}\right.$, $\mathbf{B}$, and D) In order to explore the maternal origin of the hybrids identified cytologically, rps 16 sequence was selected for phylogenetic analysis. The length of hybrids rps 16 sequences varied from 830 to $831 \mathrm{bp}$. A lot of 28 sequences were selected for ML analysis.Bromus sterilis were used as the outgroup. The data matrix contained 881 characters, 30 were variable characters and 30 were parsimony informative. TIM1 $+\mathrm{G}$ as the best-fit model (-Ln likelihood $=1555.21$ ) was used in phylogenetic analysis. The ML tree was displayed in Figure 9. The phylogenetic analyses of the rps 16 sequence were shown in Figure 9. The rps16 sequences from hybrids RH1 were grouped with $R$. stricta $(\mathrm{BS}=64 \%, \mathrm{PP}=0.97)$. The clade contained 5 hybrids RH1 sequences and $R$. stricta. The rps 16 sequences from hybrids RH2 were grouped with $R$. turczaninovii ( $\mathrm{BS}=88 \%, \mathrm{PP}=1.00$ ). The clade contained 10 hybrids $\mathrm{RH} 2$ sequences and $R$. turczaninovii. The above results showed that $R$. stricta was the maternal donor of the hybrids RH1, $R$. turczaninovii was the maternal donor of the hybrids RH2.

\section{4 | DISCUSSION}




\subsection{Identification of natural hybrids}

$R$. stricta and $R$. turczaninovii were planted in the experimental base of SAGS. We collected the seeds of the two species and planted them individually. We found that there were randomly distributed sterile plants in the experiment field. These sterile plants grew stronger than around plants and their seed set is very low (Figures 1a-c and 3). They were morphologically intermediate between $R$. strictaand $R$. turczaninovii, such as pubescence of leaf, basal leaf sheath and stem node (Figures 1d-o). We hypothesized that the plants were hybrids of $R$. stricta and $R$. turczaninovii .

Karyotype analysis showed that 57 putative natural hybrids were tetraploids, $2 \mathrm{n}=4 \mathrm{x}=28$ (Figure 4 ). Chromosomal pairing analysis showed that meiosis of $R$. stricta and $R$. turczaninovii were more regular than the putative hybrids (Figure 5). Except for hybrid RH2-31, all hybrids had univalent at MI. Univalent varying from 0.42 to 2.00 in hybrids RH1, whereas it varying from 0 to 3.45 in hybrids RH2 (Table S2). In all hybrids, the c-value was higher than 0.81 , indicating that chromosome pairing of the hybrids was comparatively regular, and had two sets of homology genomes.

FISH analysis using $\mathrm{St}_{2}-80$ showed that the 14 chromosomes of $R$. stricta,$R$. turczaninovii and the natural hybrids displayed St type (Figures 6a, c, e and 7a, c, e), indicating that they contained one set of the $\mathbf{S t}$ genome. This result was confirmed by GISH, where 28 chromosomes were hybridized with the StY probe from $R$. ciliaris (Figures $6 \mathrm{~b}, \mathrm{~d}, \mathrm{f}$ and $7 \mathrm{~b}, \mathrm{~d}, \mathrm{f}$ ). The results of in situ hybridization showed that the genomic constitution of the parents and hybrids was StY.

The above results indicated that these hybrids were tetraploids with theStY genome.

\subsection{Origin of hybrids RH1 and RH2}

Single copy nuclear gene is inherited from both parents and is rarely affected by concerted evolution. Therefore, it is used as an ideal DNA sequence in the analysis of plant molecular phylogeny to study the relationship of related species, polyploid plant phylogenetic relationship, speciation history of allopolyploid, source of species genome donor, generation of hybridization events, and gene introgression of polyploid species have significant advantages (Sang, 2002; Tang et al., 2017). In the present study, we performed phylogenetic analyses of the hybrids, the associated species ( $R$. stricta, $R$. turczaninovii, $R$. grandis, E. sibiricus) and other Triticeae species with different genomic compositions. Two distinct $D M C 1$ copies of the sequences from hybrids, $R$. stricta, $R$. turczaninovii and the other Triticeae species growing nearby were divided into St and Y clades (Figure 8). In theSt clade, 15 hybrids sequences and $R$. turczaninoviiformed a subclade ( $\mathrm{BS}=51 \%, \mathrm{PP}=1.00)$. In the $\mathbf{Y}$ clade, 15 hybrids sequences, $R$. turczaninovii and $R$. stricta formed a subclade $(\mathrm{BS}=64 \%, \mathrm{PP}=0.83)$. The results of phylogenetic analysis based on nuclear gene $D M C 1$ showed that natural hybrids have close relationships with $R$. stricta and $R$. turczaninovii, and they all contained $\mathbf{S t}$ and $\mathbf{Y}$ genomes. The results were consistent with cytological studies. Phylogenetic analyses based on rps 16 sequence showed 5 hybrids RH1 sequences were grouped with $R$. stricta ( $\mathrm{BS}=64 \%, \mathrm{PP}=0.97$ ), 10 hybrids $\mathrm{RH} 2$ sequences were grouped with $R$. turczaninovii $(\mathrm{BS}=87 \%, \mathrm{PP}=1.00)$. Furthermore, hybrids $\mathrm{RH} 1$ were collected from $R$. stricta, hybrids RH2 were collected from $R$. turczaninovii. So, $R$. stricta was the female parent of the hybrids RH1, $R$. stricta was the female parent of the hybrids RH2.

Therefore, based on the results of cytological and phylogenetic analysis, we suggested that $R$. stricta and $R$. turczaninovii were the female and male parents of the hybrids RH1; $R$. turczaninovii and $R$. stricta were the female and male parents of the hybrids RH2.

\section{3 | Formation process of natural hybrids}

Under natural conditions, hybridization was one of the main evolutionary mechanisms of plants (Goulet et al., 2017; Soltis \& Soltis 2009). Although some large families and genera were difficult to produce hybrids (Ellstrand et al., 1996), there were also frequent interspecific hybridizations of several genera, such as Asplenium (Lee et al., 2015), Senecio (Abbott \& Lowe, 2004), Betula (Wang et al., 2014), Rhododendron (Yan et al., 2013), etc. Triticeae was a young group, there was a large possibility of random hybridization among the relative genera in the Triticeae (Barkwoth \& Bothmer, 2009). The generation of natural hybrids 
was affected by the genomic constitution of species, pollination habits and environmental conditions. In addition to the overlapping or very close distribution, the parents of natural hybridization also needed to be close in flowering stage. For example, the flowering stage of Begonia crassirostrisand Begonia hemsleyana have lasted for several months, which increasing the possibility of flowering encounters with other species, so it was more likely to occur hybridization (Tian, 2017). The good open-air environment and close planting, favorable conditions were created for the occurrence of natural hybridization.

In this study, different genera species with different genome constitutions in Triticeae were planted in the experiment base of the SAGS, such as Roegneria (StY), Elymus(StH ) etc. Due to these plants were perennials, they could be kept in the field for more than ten years. The two adjacent fields are planted with $R$. stricta and $R$. turczaninovii, respectively. After three years of planting, we collected their seeds respectively and individually planted them for expanding propagation. There were about 400 plants in the $R$. stricta field, and about 330 plants in the $R$. turczaninovii field. We found some putative natural hybrids randomly distributed in these fields. The natural hybrids morphologically combined some unique characteristics (Figure 1d-o) of the two species. R. stricta was similar to $R$. turczaninovii in flowering time and their distribution areas was also close, which provided conditions for the natural hybridization.

We selected 20 basic genomic species (representing the genomesSt $, \mathbf{H}, \mathbf{E}^{\mathbf{e}}, \mathbf{E}^{\mathbf{b}}, \mathbf{W}, \mathbf{P}, \mathbf{I}, \mathbf{T a}, \mathbf{V}$, Ns , A , B , and D ) of Triticeae, hybrids and associated species growing around hybrids for phylogenetic analysis. The results indicated that 15 natural hybrids have close relationships with $R$. stricta and $R$. turczaninovii . We speculated that the hybrids were produced by the hybridization between $R$. stricta and R. turczaninoviiin this study. Their ploidy and the genomic constitution were the same, the distribution area was close, and the flowering time was synchronous, all of which form a favorable environment and factors for natural hybridization. In the process growing, their pollen pollinated each other and underwent natural hybridization to form natural hybrids.

From the perspective of hybridization rate, there were 23 hybrids out of the about $400 R$. stricta plants, and the natural hybridization rate was about $5.75 \%$, while among the about $330 R$. turczaninoviiplants, there were 54 hybrids, natural hybridization rate was about $16.36 \%$. It can be seen that natural hybridization rate of $R$. turczaninovii was about 3 times that of $R$. stricta. The reason may be that the source of the $R$. stricta parents was single and the genetic diversity was low, while the $R$. turczaninovii parent has higher genetic diversity. Large morphological differences were observed in the field of $R$. turczaninovii, which leaded to a higher natural hybridization rate. The genetic diversity of the $R$. stricta parents and $R$. turczaninovii parents needed to be further verified by molecular markers or other methods.

\subsection{Hybrid speciation}

Hybridization was increasingly recognized as an important component of species evolution (Mallet, 2005; Mallet et al., 2016; Stukenbrock, 2016). New species were produced by different ways of evolution, such as polyploidization, homoploid hybridization, and introgressive hybridization (Rieseberg \& Carney, 1998; Wang, 2017). Due to the abundant genetic and phenotypic variation in the hybrid progeny population, the boundaries between them and their parents became blurred and difficult to distinguish (Abbott, 2003). Therefore, in the past, botanists only defined a new species according to morphological characteristics, which was easy to lead to the wrong understanding of species. In other words, some previously published species were likely to be hybrid or intermediate state of hybrid transition to new species. For example, in the Triticeae, Zeng (2011) through cytology and DNA sequence analysis showed that Kengyilia stenachyra is a natural hybrid of $K$. rigidula and Elymus nutans, rather than a real species. Hybrid progeny population was highly variable, which retained the important transition types in the evolution process, and was an indispensable part of the material system to explore the formation mechanism of hybrid speciation (Rieseberg, 1997). So, the natural hybrids found in this study provided a good research material for exploring the formation. Further research will be needed on the formation of hybrid species.

\section{5 | Utilization of natural hybrids}

Heterosis was a very important biological phenomenon that hybrids surpass parents in individual size, via- 
bility, fertility, environmental adaptability, yield and quality (Shull, 1908). Breeders have long used heterosis as a means of genetic improvement (Keeble, 1910). In this study, we found some natural hybrids with good forage traits in plant height, tillers, and leaf, but the fertility was very low. If these natural hybrids could be genetically improved to create new forage varieties, it would have good ecological and economic benefits. We had found an increase in fertility in hybrid $\mathrm{F}_{2}(\sim 25 \%)$. We will continue to self-cross the hybrids to improve fertility.

\section{ACKNOWLEDGMENTS}

The authors are thankful to the National Natural Science Foundation of China (Grant Nos. 31870309 and 31670331) and the Science and Technology Bureau of Sichuan Province (2021NZZJ0010, 21YYJSYJ0083) for their financial supports.

\section{AUTHOR CONTRIBUTION}

Chen Chen : Conceptualization (Equal); Formal analysis (Lead); Investigation (Lead); Methodology (Equal); Project administration (Equal); Writing-original draft (Lead); Writing-review \& editing (Equal). Zilue Zheng : Conceptualization (Equal); Data curation (Equal); Formal analysis (Equal); Investigation (Equal); Software (Lead); Writing-original draft (Equal); Writing-review \& editing (Equal). Dandan Wu : Conceptualization (Equal); Data curation (Equal); Formal analysis (Equal); Resources (Supporting); Software (Equal); Supervision (Equal); Visualization (Equal). Lu Tan : Formal analysis (Equal); Investigation (Supporting); Software (Equal).Cairong Yang : Conceptualization (Supporting); Methodology (Supporting). Songqing Liu : Resources (Supporting).Jiale Lu : Project administration (Supporting); Supervision (Supporting); Validation (Supporting). Xing Fan : Software (Supporting). Lina Sha : Visualization (Supporting).Houyang Kang: Supervision (Supporting). Yi Wang : Validation (Supporting).Yonghong Zhou : Validation (Supporting).Changbing Zhang : Data curation (Equal); Project administration (Equal); Resources (Equal); Supervision (Equal). Haiqin Zhang : Conceptualization (Equal); Funding acquisition (Lead); Investigation (Equal); Project administration (Equal); Resources (Equal); Supervision (Lead); Writing-original draft (Equal); Writing-review \& editing (Equal).

\section{DATA ACCESSIBILITY}

Data are available from the Dryad Digital Repository at https:// doi.org/10.5061 /dryad.v41ns1rw9. The haplotype sequences of our study involved are deposited in GenBank with accession numbers MZ130327MZ130377.

\section{REFERENCES}

1. Abbott, R.J. \& Lowe, A.J. (2004). Origins, establishment and evolution of new polyploid species: Senecio cambrensis and S. eboracensis in the British Isles. Biological Journal of the Linnean Society, 82: 467-474. https://doi.org/10.1111/ j.1095-8312.2004.00333.x

2. Abbott, R.J. (2003). Sex, sunflowers, and speciation. Science, 301: 1189-1190.

3. Barkwoth, M.E., \& Bothmer, R.V. (2009). Scientific Names in the Triticeae. Genetics and Genomics of the Triticeae, 3-30.

4. Dewey, D.R. (1984). The genomic system of classification as a guide to intergeneric hybridization with the perennial Triticeae. In J.P. Gustafson (Ed), Gene Manipulation in Plant Improvement (pp. 209-279). New York, Columbia University Press.

5. Ellstrand, N.C., Whitkus, R.W. \& Rieseberg, L.H. (1996). Distribution of spontaneous plant hybrids. Proceedings of the National Academy of Sciences, USA, 93: 5090-5093. https://doi.org/10.1073/pnas.93.10.5090

6. Felsenstein, J. (1985). Confidence limits on phylogenies: an approach using the bootstrap. Evolution, 39: 783-791. https://doi.org/10.1111/j.1558 5646.1985. tb00420.x

7. Keng, Y. (1984). Flora Illustrata Plantarum Primarum Sinicarum (Gramineae). Beijing, Science Press.

8. Gill, B.S., Friebe, B., \& Endo, T.R. (1991). Standard karyotype and nomenclature system for description of chromosome bands and structural aberrations in wheat (Triticum aestivum ). Genome, 34: 
830-839. https://doi.org/10.1139/G91-128

9. Goulet, B.E., Roda, F., \& Hopkins, R. (2017). Hybridization in plants: old ideas, new techniques. Plant Physiology, 173(1): 65-78. https://doi.org/10.1104/pp.16.01340

10. Guindon, S., Delsuc, F., Dufayard, J.F., \& Gascuel, O. (2009). Estimating maximum likelihood phylogenies with PhyML. Methods in Molecular Biology, 537: 113-137. https://doi.org/10.1007/9781-59745-251-9_6

11. Guo, B. (1987). Flora Reipublicae Popularis Sinicae, Beijing: Science Press.

12. Han, F., Liu, B., Fedak, G., \& Liu, Z. (2004). Genomic constitution and variation in five partial amphiploids of wheat - Thinopyrumintermedium as revealed by GISH, multicolor GISH and seed storage protein analysis. Theoretical and Applied Genetics, 109(5): 1070-1076. https://doi.org/10.1007/s00122-004-1720-y

13. Keeble, F., \& Pellew, C. (1910). The mode of inheritance of stature and time of flowering in peas (Pisum sativum ). Journal of Genetics, 1: 47-56. https://doi.org/10.1007/BF01798042

14. Lee, C.S., Lee, K., Yeau, S.H. \& Chung, K.S. (2015). Two new and one unrecorded natural hybrids between Asplenium ruprechtii and related taxa (Aspleniaceae). Korean Journal of Plant Taxonomy, 45: 362-368. https://doi.org/10.11110/kjpt. 2015.45.4.362

15. Lei, Y., Liu, J., Fan, X., Sha, L., Wang, Y., Kang, H., .. Zhang, H. (2018). Phylogeny and molecular evolution of the $D M C 1$ gene in the polyploid genus Roegneria and its affinitive genera (Poaceae: Triticeae). Botanical Journal of the Linnean Society, 186, 129-142. https://doi.org/10.1093/botlinnean/box081

16. Mallet, J. (2005). Hybridization as an invasion of the genome. Trends in Ecology \& Evolution, 20: 229-237. https://doi.org/10.1016/j.tree.2005.02.010

17. Mallet, J., Besansky, N., \& Hahn, M.W. (2016). How reticulated are species? BioEssays, 38: 140-149. https://doi.org/10.1002/bies.201500149

18. Mao, J., Ma, Y., \& Zhou, R.C. (2017). Approaches used to detect and test hybridization: combining phylogenetic and population genetic analyses. Biodiversity Science, 25: 577-599.

19. Murray, H.G., \& Thompson, W.F. (1980). Rapid isolation of high molecular weight plant DNA. Nucleic Acids Research, 8: 4321-4325. https://doi.org/10.1093/NAR/ 8.19.4321

20. Paštová, L., Belyayev, A., \& Mahelka, V. (2019). Molecular cytogenetic characterisation of Elytrigia $\times$ mucronata, a natural hybrid of E. intermedia and E. repens(Triticeae, Poaceae). BMC Plant Biology, 19(1): 230. https://doi.org/10.1186/s12870-019-1806-y

21. Petersen, G., \& Seberg, O. (2002). Molecular evolution and phylogenetic application $D M C$ 1. Molecular Phylogenetics and Evolution, 22 (1): 43-50. https://doi.org/10.1006/mpev.2001.1011

22. Posada, D., \& Crandall, K.A. (1998). MODELTEST: testing the model of DNA substitution. Bioinformatics, 14: 817-818. https://doi.org/10.1093/bioinformatics /14.9.817

23. Quijada, A., Liston, A., Robinson, W., \& Alvarez-buylla, E. (1997). The ribosomal ITS region as a marker to detect hybridization in pines. Molecular Ecology, 6: 995-996. https://doi.org/10.1046/j.1365294X.1997.t01-1-00273.x

24. Rauscher, J.T., Doyle, J.J., \& Brown, A.H.D. (2002). Internal transcribed spacer repeat-specific primers and the analysis of hybridization in the Glycine tomentella (Leguminosae) polyploid complex. Molecular Ecology, 11(12): 2691-2702. https://doi.org/10.1046/j.1365-294X.2002.01640.x

25. Rieseberg, L.H. (1995). The role of hybridization in evolution: old wine in new skins. American Journal of Botany, 82: 944-953. https://doi.org/10.1002/J.1537-2197.1995.TB15711.X

26. Rieseberg, L.H. (1997). Hybrid origins of plant species. Annual Review of Ecology \& Systematics, 28(28): 359-389.

27. Rieseberg, L.H., \& Carney, S.E. (1998). Plant hybridization. New Phytologist, 140(4): 599-624.

28. Ronquist, F., \& Huelsenbeck, J.P. (2003). MRBAYES 3: Bayesian phylogenetic inference under mixed model. Bioinformatics, 19: 1572-1574. https://doi.org/10.1093/bioinformatics/btg180

29. Sang, T. (2002). Utility of low-copy nuclear gene sequences in plant phylogenetics. Critical Reviews in Biochemistry and Molecular Biology, 37(3): 121-147. https://doi.org/10.1080/10409230290771474

30. Sang, T., Crawford, D.J., \& Stuessy, T.F. (1995). Documentation of reticulate evolution in peonies 
(Paeonia ) using internal transcribed spacer sequences of nuclear ribosomal DNA: implications for biogeography and concerted evolution. Proceedings of the National Academy of Sciences of the United States, 92: 6813-6817. https://doi.org/10.1073/pnas.92.15.6813

31. Sha, L., Fan, X., Yang, R., Kang, H., Ding, C., Zhang, L., ... Zhou, Y. (2010). Phylogenetic relationships between Hystrix and its closely related genera (Triticeae; Poaceae) based on nuclear Acc 1, DMC 1 and chloroplast trnL -Fsequences. Molecular Phylogenetics and Evolution, 54: 327-335. https://doi.org/10.1016/ j.ympev.2009.05.005

32. Shaw, J., Lickey, E.B., Beck, J.T., Farmer, S.B., Liu, W., Miller, J., .. Small, R.L. (2005). The tortoise and the hare II: relative utility of 21 noncoding chloroplast DNA sequences for phylogenetic analysis. American Journal of Botany, 92: 142-166. https://doi.org/10.3732/ajb.92.1.142

33. Shull, G.H. (1908). The composition of a field of maize. Journal of Heredity, , 4: 296-301. https://doi.org/10.1093/jhered/os-4.1.296

34. Smith, J.F., Funke, M.M., \& Woo, V.L. (2006). A duplication of gcyc predates divergence within tribe Coronanthereae (Gesneriaceae): phylogenetic analysis and evolution. Plant Systematics and Evolution, 261(1-4): 245-256. https://doi.org/10.1007/s00606-006-0445-6

35. Soltis, D.E., \& Soltis, P.S. (1993). Molecular data and the dynamic nature of polyploidy. Critical Reviews in Plant Sciences, 12: 243-273. https://doi.org/10.1080/07352689309701903

36. Soltis, P.S., \& Soltis, D.E. (2009). The role of hybridization in plant speciation. Annual Review of Plant Biology, 60: 561-588. https://doi.org/10.1146/ annurev.arplant.043008.092039

37. Soltis, P.S., Doyle, J.J., \& Soltis, D.E. (1992). Molecular data and polyploid evolution in plants. In P.S. Soltis, D.E. Soltis, \& J.J. Doyle (Eds.), Molecular Systematics of Plant (pp. 177 -201). New York, NY: Chapman \& Hall.

38. Stebbins, G.L., \& Singh, R. (1950). Artificial and natural hybrids in the Gramineae, Tribe Hordeae. IV. Two triploid hybrids of Agropyron and Elymus . American Journal of Botany, 37(5): 388-393.

39. Stebbins, G.L., \& Vaarama, A. (1954). Artificial and natural hybrids in the Gramineae, Tribe Hordeae. VII. Hybrids and allopolyploids betweenElymus glaucus and Sitanion spp. Genetics, 39(3): 378-395.

40. Stebbins, G.L., \& Walters, M.S. (1949). Artificial and natural hybrids in the Gramineae, Tribe Hordeae. III. Hybrids involving Elymus condensatus and E. triticoides . American Journal of Botany, 36(3): 291301.

41. Stukenbrock, E.H. (2016). The role of hybridization in the evolution and emergence of new fungal plant pathogens. Phytopathology, 106: 104-112. https://doi.org/10.1094/PHYTO-08-15-0184-RVW

42. Tang, C., Qi, J., Chen, N., Sha, L., Wang, Y., Zeng, J., ... Fan X. (2017). Genome origin and phylogenetic relationships of Elymus villosus (Triticeae: Poaceae) based on single-copy nuclear Acc 1, Pgk 1, DMC 1 and chloroplasttrnL $-F$ sequences. Biochemical Systematics and Ecology, 70: 168-176. https://doi.org/10.1016/j.bse.2016.11.011

43. Tian, D., Li, C., Xiao, Y., Fu, N., Tong, Y., \& Wu, R. (2017). Occurrence and characteristics of natural hybridization ofBegonia from China. Biodiversity Science, 25: 654-674. https://doi.org/10.17520/biods.2017050

44. Von Tschermak, E., \& Bleier, H. (1926). Über fruchtbareAegilops -Weizenbastarde. Berichte der Deutschen Botanischen Gesellschaft, 44: 110-132.

45. Wang, L., Shi, Q., Su, H., Wang, Y., Sha, L., Fan, X., ... Zhou, Y. (2017). St2-80: a new FISH marker for St genome and genome analysis in Triticeae. Genome, 60: 553-563. https://doi.org/10.1139/gen2016-0228

46. Wang, N., Borrell, J.S., Bodles, W.J., Kuttapitiya, A., Nichols, R.A. \& Buggs, R.J.A. (2014). Molecular footprints of the Holocene retreat of dwarf birch in Britain. Molecular Ecology, 23: 2771-2782. https://doi.org/10.1111/mec.12768

47. Wang, Y. (2017). Natural hybridization and speciation. Biodiversity Science, 25(6): 565-576.

48. Yan, C., Hu, Q., Sun, G., \& McIntyre, C.L. (2014). Nuclear and chloroplast DNA phylogeny reveals complex evolutionary history ofElymus pendulinus . Genome, 57(2): 97-109. https://doi.org/10.1139/gen2014-0002

49. Yan, L., Gao, L., \& Li, D. (2013). Molecular evidence for natural hybridization between Rhododen- 
dron spiciferum and R. spinuliferum (Ericaceae). Journal of Systematics and Evolution, 51: 426-434. https://doi.org/10.1111/j.1759-6831.2012.00243.x

50. Yang, J., Baum, B.R., \& Yen, C. (2008). A revision of the genusRoegneria C. Koch (Poaceae: Triticeae). Journal of Sichuan Agricultural University, 26: 311-381.

51. Yu, Y., Than, C., Degnan, J.H., \& Nakhleh L. (2011). Coalescent histories on phylogenetic networks and detection of hybridization despite incomplete lineage sorting. Systematic Biology, 60: 138-149. https://doi.org/10.1093/sysbio/syq084

52. Zeng, J. (2011). Molecular Phylogenetic Study on Kengyilia C. Yen Et J.L. Yang and Molecular Cytogenetic Analysis of New Breeding Resources Derived fromElytrigia Desv. (Triticeae: Poaceae). Sichuan Agricultural University.

53. Zeng, J., Fan, X., Zhang, H., Sha, L., Kang, H., Zhang, L., ... Zhou, Y. (2012). Molecular and cytological evidences for the natural wheat grass hybrids occurrence and origin in west China. Genes \& Genomics, 34: 499-507. https://doi.org/10.1007 /s13258-012-0057-1

54. Zhang, H., \& Zhou, Y. (2006). Meiotic pairing behaviour reveals differences in genomic constitution between Hystrix patula and other species of genus Hystrix Moench (Poaceae, Triticeae). Plant Systematics and Evolution, 258: 129-136. https://doi.org/10.1007/s00606-005-0394-5

55. Zhang, H., Fan, X., Wang, Y., \& Zhou, Y. (2008). Cytogenetic studies of intergeneric hybrids between Roegneria ciliaris andLeymus multicaulis (Poaceae: Triticeae). Acta Prataculturae Sinica, 17: 162-165.

56. Zhou, Y., Yen, C., \& Yang, J. (1995). A study on the intergeneric hybrid of R. kamoji $\times$ Hordeum vulgare. Journal of Sichuan Agricultural University, 13: 144-149.

TABLE 1 The materials used in this study

\begin{tabular}{lllllll}
\hline Parents and hybris & Accession No. & Genomes & 2n & Plants No. & Origins & Origins \\
\hline Roegneria turczaninovii & ZY 11140 & StY & 28 & 6 & 6 & Inner Mongolia, china \\
Roegneria stricta & Y 2102 & StY & 28 & 14 & 14 & Sichuan, China \\
Hybrid & RH1-1 $\sim$ RH1-17 & - & - & 17 & 17 & Sichuan, China \\
Hybrid & RH2-1 $\sim$ RH2-40 & - & - & 40 & 40 & Sichuan, China \\
\hline
\end{tabular}

TABLE 2 Plant materials used in Phylogenetic analysis

\begin{tabular}{|c|c|c|c|c|c|c|}
\hline Number & Species/Hybrids & Genome & $2 n$ & Accesssion & Locality & $\begin{array}{l}\text { GenBank } \\
\text { No. }\end{array}$ \\
\hline & & & & & & $\begin{array}{l}D M C 1 \\
r p s 16\end{array}$ \\
\hline 1 & hybrid 1 & StY & $4 \mathrm{x}$ & RH1-3 & $\begin{array}{l}\text { Sichuan, } \\
\text { China }\end{array}$ & \\
\hline 2 & hybrid 2 & StY & $4 \mathrm{x}$ & RH1-6 & $\begin{array}{l}\text { Sichuan, } \\
\text { China }\end{array}$ & \\
\hline 3 & hybrid 3 & StY & $4 \mathrm{x}$ & RH1-8 & $\begin{array}{l}\text { Sichuan, } \\
\text { China }\end{array}$ & \\
\hline 4 & hybrid 4 & StY & $4 \mathrm{x}$ & RH1-12 & $\begin{array}{l}\text { Sichuan, } \\
\text { China }\end{array}$ & \\
\hline 5 & hybrid 5 & StY & $4 \mathrm{x}$ & RH1-14 & $\begin{array}{l}\text { Sichuan, } \\
\text { China }\end{array}$ & \\
\hline 6 & hybrid 6 & StY & $4 \mathrm{x}$ & RH2-2 & $\begin{array}{l}\text { Sichuan, } \\
\text { China }\end{array}$ & \\
\hline 7 & hybrid 7 & StY & $4 \mathrm{x}$ & RH2-5 & $\begin{array}{l}\text { Sichuan, } \\
\text { China }\end{array}$ & \\
\hline
\end{tabular}




\begin{tabular}{|c|c|c|c|c|c|c|}
\hline Number & Species/Hybrids & Genome & $2 \mathrm{n}$ & Accesssion & Locality & $\begin{array}{l}\text { GenBank } \\
\text { No. }\end{array}$ \\
\hline 8 & hybrid 8 & StY & $4 \mathrm{x}$ & RH2-7 & $\begin{array}{l}\text { Sichuan, } \\
\text { China }\end{array}$ & \\
\hline 9 & hybrid 9 & StY & $4 \mathrm{x}$ & RH2-10 & $\begin{array}{l}\text { Sichuan, } \\
\text { China }\end{array}$ & \\
\hline 10 & hybrid 10 & StY & $4 \mathrm{x}$ & RH2-11 & $\begin{array}{l}\text { Sichuan, } \\
\text { China }\end{array}$ & \\
\hline 11 & hybrid 11 & StY & $4 \mathrm{x}$ & RH2-13 & $\begin{array}{l}\text { Sichuan, } \\
\text { China }\end{array}$ & \\
\hline 12 & hybrid 12 & StY & $4 \mathrm{x}$ & RH2-14 & $\begin{array}{l}\text { Sichuan, } \\
\text { China }\end{array}$ & \\
\hline 13 & hybrid 13 & StY & $4 \mathrm{x}$ & RH2-15 & $\begin{array}{l}\text { Sichuan, } \\
\text { China }\end{array}$ & \\
\hline 14 & hybrid 14 & StY & $4 \mathrm{x}$ & RH2-16 & $\begin{array}{l}\text { Sichuan, } \\
\text { China }\end{array}$ & \\
\hline 15 & hybrid 15 & StY & $4 \mathrm{x}$ & RH2-17 & $\begin{array}{l}\text { Sichuan, } \\
\text { China }\end{array}$ & \\
\hline 16 & hybrid 16 & StY & $4 \mathrm{x}$ & RH2-18 & $\begin{array}{l}\text { Sichuan, } \\
\text { China }\end{array}$ & \\
\hline 17 & hybrid 17 & StY & $4 \mathrm{x}$ & RH2-30 & $\begin{array}{l}\text { Sichuan, } \\
\text { China }\end{array}$ & \\
\hline 18 & hybrid 18 & StY & $4 \mathrm{x}$ & RH2-31 & $\begin{array}{l}\text { Sichuan, } \\
\text { China }\end{array}$ & \\
\hline 19 & hybrid 19 & StY & $4 \mathrm{x}$ & RH2-37 & $\begin{array}{l}\text { Sichuan, } \\
\text { China }\end{array}$ & \\
\hline 20 & hybrid 20 & StY & $4 \mathrm{x}$ & RH2-39 & $\begin{array}{l}\text { Sichuan, } \\
\text { China }\end{array}$ & \\
\hline 21 & $\begin{array}{l}\text { Putative } \\
\text { parent } \\
\text { Roegneria } \\
\text { strictus } \\
\text { (Keng) } \\
\text { S.L.Chen }\end{array}$ & StY & $4 \mathrm{x}$ & Y 2102 & $\begin{array}{l}\text { Sichuan, } \\
\text { China }\end{array}$ & \\
\hline Number & Species/Hybrids & Genome & $2 \mathrm{n}$ & Accesssion & Locality & $\begin{array}{l}\text { GenBank } \\
\text { NO. } \\
D M C 1 \\
\text { rps } 16\end{array}$ \\
\hline 22 & $\begin{array}{l}\text { Putative } \\
\text { parent } \\
\text { Roegneria } \\
\text { turczaninovii } \\
\text { (Drobow) } \\
\text { Nevski }\end{array}$ & StY & $4 \mathrm{x}$ & ZY 11140 & $\begin{array}{l}\text { Inner } \\
\text { Mongolia, } \\
\text { China }\end{array}$ & \\
\hline 23 & $\begin{array}{l}\text { Elymus } \\
\text { sibiricus L. }\end{array}$ & StH & $4 \mathrm{x}$ & PI 619579 & $\begin{array}{l}\text { Xinjiang, } \\
\text { China }\end{array}$ & $\begin{array}{l}\text { EU366409* } \\
\text { GQ855198* }\end{array}$ \\
\hline 24 & $\begin{array}{l}\text { Elymus } \\
\text { caninus L. }\end{array}$ & StH & $4 \mathrm{x}$ & PI 314621 & $\begin{array}{l}\text { Former Soviet } \\
\text { Union }\end{array}$ & $\begin{array}{l}\text { EU366407* } \\
\text { EU366408* }\end{array}$ \\
\hline 25 & $\begin{array}{l}\text { Elymus } \\
\text { elymoides } \\
\text { (Raf.) Swezey }\end{array}$ & StH & $4 \mathrm{x}$ & PI 628684 & United States & $\begin{array}{l}\text { FJ695161* } \\
\text { FJ695160* }\end{array}$ \\
\hline
\end{tabular}




\begin{tabular}{|c|c|c|c|c|c|c|}
\hline Number & Species/Hybrids & Genome & $2 \mathrm{n}$ & Accesssion & Locality & $\begin{array}{l}\text { GenBank } \\
\text { No. }\end{array}$ \\
\hline 26 & $\begin{array}{l}\text { Elymus } \\
\text { glaucus } \\
\text { Buckley }\end{array}$ & StH & $4 \mathrm{x}$ & PI 593652 & $\begin{array}{l}\text { Oregon United } \\
\text { States }\end{array}$ & $\begin{array}{l}\text { FJ695163* } \\
\text { FJ695162* }\end{array}$ \\
\hline 27 & $\begin{array}{l}\text { Elymus } \\
\text { virginicus L. }\end{array}$ & StH & $4 \mathrm{x}$ & $\begin{array}{l}\text { PI } 490361 \mathrm{PI} \\
882397\end{array}$ & $\begin{array}{l}\text { United States } \\
\text { Sichuan, } \\
\text { China }\end{array}$ & $\begin{array}{l}\text { GQ855195* } \\
\text { GQ855196* }\end{array}$ \\
\hline 28 & $\begin{array}{l}\text { Elymus } \\
\text { wawawaiensi }\end{array}$ & StH & $4 \mathrm{x}$ & PI 506284 & $\begin{array}{l}\text { Sichuan, } \\
\text { China }\end{array}$ & \\
\hline 29 & $\begin{array}{l}\text { Roegneria } \\
\text { caucasica K. } \\
\text { Koch }\end{array}$ & StY & $4 \mathrm{x}$ & H 3207 & $\begin{array}{l}\text { Xinjiang, } \\
\text { Armenia }\end{array}$ & $\begin{array}{l}\text { HM770785* } \\
\text { HM770784* }\end{array}$ \\
\hline 30 & $\begin{array}{l}\text { Roegneria } \\
\text { ciliaris(Trin.) } \\
\text { Nevski }\end{array}$ & StY & $4 \mathrm{x}$ & $\begin{array}{l}87-88335 \\
88-89-238\end{array}$ & $\begin{array}{l}\text { Sichuan, } \\
\text { China }\end{array}$ & $\begin{array}{l}\text { KU160610* } \\
\text { KU160617* }\end{array}$ \\
\hline 31 & $\begin{array}{l}\text { Roegneria } \\
\text { dura Keng }\end{array}$ & StY & $4 \mathrm{x}$ & Y 2124 & $\begin{array}{l}\text { Neimenggu, } \\
\text { China }\end{array}$ & KX578879* \\
\hline 32 & $\begin{array}{l}\text { Roegneria } \\
\text { grandis Keng }\end{array}$ & StY & $4 \mathrm{x}$ & $\begin{array}{l}\text { ZY } 3189 \mathrm{Y} \\
3189\end{array}$ & Xizang, China & $\begin{array}{l}\text { KU160615* } \\
\text { KU160618* }\end{array}$ \\
\hline 33 & $\begin{array}{l}\text { Roegneria } \\
\text { hondai } \\
\text { Kitagawa }\end{array}$ & StY & $4 \mathrm{x}$ & Y 0362 & $\begin{array}{l}\text { Sichuan, } \\
\text { China }\end{array}$ & $\begin{array}{l}\mathrm{KX} 578840^{*} \\
\mathrm{KX} 578841^{*}\end{array}$ \\
\hline Number & Species/Hybrids & Genome & $2 \mathrm{n}$ & Accesssion & Locality & $\begin{array}{l}\text { GenBank } \\
\text { NO. } \\
D M C 1 \\
\text { rps } 16\end{array}$ \\
\hline 34 & $\begin{array}{l}\text { Roegneria } \\
\text { longearistata } \\
\text { (Boiss.) } \\
\text { Drob. }\end{array}$ & StY & $4 \mathrm{x}$ & Y 2259 & $\begin{array}{l}\text { Inner } \\
\text { Mongolia, } \\
\text { China }\end{array}$ & KX578848 \\
\hline 35 & $\begin{array}{l}\text { Roegneria } \\
\text { shandongensis } \\
\text { (B. Salomon) } \\
\text { J. L. Yang \& } \\
\text { C.Yen }\end{array}$ & StY & $4 \mathrm{x}$ & ZY 3150 & Shanxi, China & KX578862* \\
\hline 36 & $\begin{array}{l}\text { Roegneria } \\
\text { ugamica } \\
\text { (Drob.) } \\
\text { Nevski }\end{array}$ & StY & $4 \mathrm{x}$ & Y 1698 & $\begin{array}{l}\text { Sichuan, } \\
\text { China }\end{array}$ & $\begin{array}{l}\mathrm{KX} 578877^{*} \\
\mathrm{KX} 578878^{*}\end{array}$ \\
\hline 37 & $\begin{array}{l}\text { Pseudoroegneria } \\
\text { libanotica } \\
\text { (Hackel) D. R. } \\
\text { Dewey }\end{array}$ & St & $2 \mathrm{x}$ & $\begin{array}{l}\text { PI } 228389 \text { PI } \\
228392\end{array}$ & Iran & FJ695174* \\
\hline 38 & $\begin{array}{l}\text { Pseudoroegneria } \\
\text { spicata } \\
\text { (Pursh) A. } \\
\text { Löve }\end{array}$ & St & $2 \mathrm{x}$ & $\begin{array}{l}\text { PI } 547161 \text { PI } \\
632532\end{array}$ & United States & $\begin{array}{l}\text { FJ695175* } \\
\text { KY636118* }\end{array}$ \\
\hline
\end{tabular}




\begin{tabular}{|c|c|c|c|c|c|c|}
\hline Number & Species/Hybrids & Genome & $2 \mathrm{n}$ & Accesssion & Locality & $\begin{array}{l}\text { GenBank } \\
\text { No. }\end{array}$ \\
\hline 39 & $\begin{array}{l}\text { Pseudoroegneria } \\
\text { stipifolia } \\
\text { (Czern. ex } \\
\text { Nevski) }\end{array}$ & St & $2 \mathrm{x}$ & PI 325181 & $\begin{array}{l}\text { Stavropol, } \\
\text { Russian }\end{array}$ & FJ695176* \\
\hline 40 & $\begin{array}{l}\text { Pseudoroegneria } \\
\text { strigosa (M. } \\
\text { Bieb.) A. Löve }\end{array}$ & St & $2 \mathrm{x}$ & $\begin{array}{l}\text { PI } 595164 \text { PI } \\
499637\end{array}$ & $\begin{array}{l}\text { Xinjiang, } \\
\text { China }\end{array}$ & FJ695177* \\
\hline 41 & $\begin{array}{l}\text { Pseudoroegneria } \\
\text { tauri (Boiss.) } \\
\text { A. Löve }\end{array}$ & St & $2 \mathrm{x}$ & $\begin{array}{l}\text { PI } 401329 \\
\text { PI380650 }\end{array}$ & Iran & KU160613 \\
\hline 42 & $\begin{array}{l}\text { Agropyron } \\
\text { cristatus (L.) } \\
\text { Gaertn }\end{array}$ & $\mathbf{P}$ & $2 \mathrm{x}$ & $\begin{array}{l}\text { H } 4349 \text { PI } \\
598628\end{array}$ & $\begin{array}{l}\text { China } \\
\text { Kazakhstan }\end{array}$ & $\begin{array}{l}\text { AF277241* } \\
\text { KY126307* }\end{array}$ \\
\hline 43 & $\begin{array}{l}\text { Australopyrum } \\
\text { retrofractum } \\
\text { (Vickery) A. } \\
\text { Löve }\end{array}$ & $\mathbf{W}$ & $2 \mathrm{x}$ & $\begin{array}{l}\text { H } 6723 \text { PI } \\
531553\end{array}$ & $\begin{array}{l}\text { China United } \\
\text { States }\end{array}$ & $\begin{array}{l}\text { AF277251* } \\
\text { KY636080.1* }\end{array}$ \\
\hline 44 & $\begin{array}{l}\text { Hordeum } \\
\text { chilense } \\
\text { Roem. \& } \\
\text { Schult. }\end{array}$ & $\mathbf{H}$ & $2 \mathrm{x}$ & PI 531781 & Chile & FJ695173* \\
\hline 45 & $\begin{array}{l}\text { Hordeum } \\
\text { pubiflorum } \\
\text { Hook.f. }\end{array}$ & $\mathbf{H}$ & $2 \mathrm{x}$ & BCC 2028 & & KY636108* \\
\hline 46 & $\begin{array}{l}\text { Hordeum } \\
\text { bogdanii } \\
\text { Wilensky }\end{array}$ & $\mathbf{H}$ & $2 \mathrm{x}$ & PI 531761 & China & $\begin{array}{l}\text { FJ695172* } \\
\text { MH331641* }\end{array}$ \\
\hline Number & Species/Hybrids & Genome & $2 n$ & Accesssion & Locality & $\begin{array}{l}\text { GenBank } \\
\text { NO. } \\
D M C 1 \\
\text { rps } 16\end{array}$ \\
\hline 47 & $\begin{array}{l}\text { Hordeum } \\
\text { vulgare L. }\end{array}$ & $\mathbf{I}$ & $2 \mathrm{x}$ & H 3878 & Italy & EF115541* \\
\hline 48 & $\begin{array}{l}\text { Lophopyrum } \\
\text { elongatum } \\
\text { (Host) A. Löve }\end{array}$ & $\mathbf{E}^{\mathrm{e}}$ & $2 \mathrm{x}$ & $\begin{array}{l}\text { PI } 531719 \\
\text { PI531718 }\end{array}$ & Israel & $\begin{array}{l}\text { AF277246* } \\
\text { MH331643* }\end{array}$ \\
\hline 49 & $\begin{array}{l}\text { Thinopyrum } \\
\text { bessarabicum } \\
\text { (Savul. \& } \\
\text { Rayss) A. }\end{array}$ & $\mathbf{E}^{\mathbf{b}}$ & $2 \mathrm{x}$ & $\begin{array}{l}\text { PI } 531711 \text { W6 } \\
21890\end{array}$ & Russia & $\begin{array}{l}\text { AF277254* } \\
\text { KY636145* }\end{array}$ \\
\hline 50 & $\begin{array}{l}\text { Psathyrostachys } \\
\text { huashanica } \\
\text { Keng ex P.C } \\
\text { Kuo }\end{array}$ & $\mathrm{Ns}$ & $2 \mathrm{x}$ & PI 531823 & $\begin{array}{l}\text { Shanxi, } \\
\text { China }\end{array}$ & GU165826* \\
\hline 51 & $\begin{array}{l}\text { Aegilops } \\
\text { speltoides } \\
\text { Tausch. }\end{array}$ & B & $2 \mathrm{x}$ & Н 6779 & & DQ247833* \\
\hline 52 & $\begin{array}{l}\text { Aegilops } \\
\text { tauschii Coss. }\end{array}$ & $\mathbf{D}$ & $2 \mathrm{x}$ & Н 6668 AE429 & & $\begin{array}{l}\text { AF277235* } \\
\text { JQ754651* }\end{array}$ \\
\hline
\end{tabular}




\begin{tabular}{|c|c|c|c|c|c|c|}
\hline Number & Species/Hybrids & Genome & $2 \mathrm{n}$ & Accesssion & Locality & $\begin{array}{l}\text { GenBank } \\
\text { No. }\end{array}$ \\
\hline$\overline{53}$ & $\begin{array}{l}\text { Dasypyrum } \\
\text { villosum (K. } \\
\text { Koch) Nevski }\end{array}$ & $\mathrm{V}$ & $2 \mathrm{x}$ & $\begin{array}{l}\text { H } 5552 \text { W6 } \\
7264\end{array}$ & & $\begin{array}{l}\text { AF277236* } \\
\text { MH285850* }\end{array}$ \\
\hline 54 & $\begin{array}{l}\text { Secale } \\
\text { cereale L. }\end{array}$ & $\mathbf{R}$ & $2 \mathrm{x}$ & & & KC912691* \\
\hline 55 & $\begin{array}{l}\text { Taeniatherum } \\
\text { copmedusae } \\
\text { (L.) Nevski }\end{array}$ & $\mathbf{T a}$ & $2 \mathrm{x}$ & $\begin{array}{l}\text { H } 10254 \\
\text { PI220591 }\end{array}$ & & $\begin{array}{l}\text { AF277249* } \\
\text { MH285856* }\end{array}$ \\
\hline 56 & $\begin{array}{l}\text { Triticum } \\
\text { urartu Tum. }\end{array}$ & $\mathbf{A}$ & $2 \mathrm{x}$ & H 6664 & & DQ247826* \\
\hline 57 & $\begin{array}{l}\text { Bromus } \\
\text { sterilis L. }\end{array}$ & & & OSA 420 & & AF277234* \\
\hline
\end{tabular}

Note: $1^{*}$ Data from published sequences in the GenBank (http://www.ncbi.nlm.nih.gov)

\section{Figure legends}

FIGURE 1 Morphological characteristics of the natural hybrids and their parents. (a) - (c) Natural distribution of hybrids. (a) hybrid RH1 (arrowed). (b) hybrid RH2 (arrowed). (c) hybrid RH1 (arrowed). (d) - (g) Leaves of hybrids and parents. (d) R. turczaninovi i (arrowed). (e) R. stricta(arrowed). (f) hybrid RH1 (arrowed). G: hybrid RH2 (arrowed). (h) - (k) Stem segments of hybrids and parents. (h) $R$. turczaninovi i (arrowed). (i) R. stricta (arrowed). (j) hybrid RH1 (arrowed). K: hybrid RH2 (arrowed). (l) - (o) Basal leaves of hybrids and parents. (l) R. turczaninovi i (arrowed). (m) R. stricta (arrowed). (n) hybrid RH1 (arrowed). O: hybrid RH2 (arrowed).

FIGURE 2 Morphological analysis of hybrids RH1, hybrids RH2, R. stricta and $R$. turczaninovii . (a) Plant height. (b) Number of tillers. (c) Length of flag leaf. (d) Width of flag leaf. (e) Length of top second leaf. (f) Width of top second leaf. (g) Length of spike. (h) Number of florets. (i) Length of awn. Note: Different letter shows the significance of difference of ANOVA.

FIGURE 3 Pollen fertility and seed set of hybrids RH1, hybrids RH2, R. stricta and R. turczaninovii

FIGURE 4 Karyotype analysis of hybrids RH1, hybrids RH2, $R$. stricta and $R$. turczaninovii. (a) $R$. turczaninovii . (b) R. stricta . (c) RH1-13. (b) RH2-10.

FIGURE 5 Meiotic associations in PMCs of the parental species and hybrids. (a) and (b) $R$. turczaninovii with 14 II. (c) R. stricta with 14 II. (d) RH1-15 with 14 II (12 ring + 2 rod). (e) RH1-7 with 13 II (9 ring +8 rod) +2 I. (f) RH2-38 lagging chromosomes. (g) RH2-29 with 14 II (12 ring and 2 rod). (h) RH2-11 with 13 II (11 ring and 2 rod) +2 I. (i) RH2-11 chromosome bridge.

FIGURE 6 Analysis of FISH and GISH in R. stricta and R. turczaninovii . (a) and (b) R. stricta . (c) (f) R. turczaninovii . (a), (c) and (e) Used $\mathrm{St}_{2}-80$ as probe (red), 14 chromosomes were labeled as St type (arrowed) and 14 chromosomes were labeled as non-St type. (b), (d) and (f) With total genomic DNA of $R$. ciliaris (StY genome) was labeled with Texas-red-5-dCTP (red) as probe, 28 chromosomes were labeled as red fluorescent signals.

FIGURE 7 Analysis of FISH and GISH in hybrids. (a) and (b) RH1-11. (c) and (d) RH2-12. E and F RH2-15. (a), (c) and (e) Using $\mathrm{St}_{2}-80$ as probe (green), 14 chromosomes were labeled as $\mathbf{S t}$ type (arrowed) and 14 chromosomes were labeled as non-St type. (b), (d) and (f) With total genomic DNA of R. ciliaris (StY genome) was labeled with fluorescein-12-dUTP (green) as probe, 28 chromosomes were labeled as green fluorescent signals. 
FIGURE 8 Phylogenetic tree based on $D M C 1$ sequences of hybrids using ML. Numbers with bold above nodes are bootstrap values, and numbers below nodes are Bayesian posterior probability values.

FIGURE 9 Phylogenetic tree based on rps 16 sequences of hybrids using ML. Numbers with bold above nodes are bootstrap values, and numbers below nodes are Bayesian posterior probability values.

supplementary material

TABLE S1 The primers used in this study

\begin{tabular}{llll}
\hline Gene & Name of primers & Sequence of primer $\left(5^{\prime}-3^{\prime}\right)$ & Profiles \\
\hline$D M C 1$ & TDMC1e10F & TGCCAATTGCTGAGAGATTTG & 1 cycle: 4 min $94 ; 35$ cycles: 1 min 94,1 min 52,2 r \\
& TDMC1e15R & AGCCACCTGTTGTAATCTGG & \\
rps 16 & rps $16 \mathrm{~F}$ & AAACGATGTGGTAGAAAGCAAC & 1 cycle: 3 min $95 ; 35$ cyclies: $40 \mathrm{~s} 94,40 \mathrm{~s} 55,1$ min \\
& rps $16 \mathrm{R}$ & ACATCAATTGCAACGATTCGATA & \\
\hline
\end{tabular}

TABLE S2 Meiotic associations at metaphase I in PMCs of the parental species and hybrid

\begin{tabular}{|c|c|c|c|c|c|}
\hline Species and hybrids & No. of cells observed & Chromosome pairing & Chromosome pairing & Chromosome pairing & Chrome \\
\hline & & I & Ring II & Rod II & Total II \\
\hline R. stricta & 463 & 0 & 13.55 & 0.44 & 13.99 \\
\hline R. turczaninovii & 198 & 0 & 13.53 & 0.43 & 13.96 \\
\hline RH1-1 & 24 & 1.6 & 11.45 & 1.75 & 13.2 \\
\hline RH1-2 & 28 & 0.9 & 12.05 & 1.6 & 13.65 \\
\hline RH1-3 & 21 & 0.6 & 12.15 & 1.55 & 13.7 \\
\hline RH1-4 & 35 & 1.9 & 11.1 & 1.95 & 13.05 \\
\hline RH1-5 & 23 & 0.93 & 10.98 & 2.53 & 13.51 \\
\hline RH1-6 & 24 & 0.5 & 12.15 & 1.65 & 13.8 \\
\hline RH1-7 & 20 & 1.1 & 10.85 & 2.6 & 13.45 \\
\hline RH1-8 & 34 & 0.53 & 11.44 & 2.29 & 13.73 \\
\hline RH1-9 & 20 & 1.3 & 11.75 & 1.6 & 13.35 \\
\hline RH1-10 & 20 & 1 & 10.7 & 2.8 & 13.5 \\
\hline RH1-11 & 25 & 0.5 & 12.15 & 1.6 & 13.75 \\
\hline RH1-12 & 21 & 0.9 & 11.75 & 1.8 & 13.55 \\
\hline RH1-13 & 35 & 0.51 & 11.97 & 1.77 & 13.74 \\
\hline RH1-14 & 20 & 2 & 11.5 & 1.5 & 13 \\
\hline RH1-15 & 20 & 1.2 & 11.15 & 2.25 & 13.4 \\
\hline RH1-16 & 20 & 0.8 & 12 & 1.6 & 13.6 \\
\hline RH1-17 & 32 & 0.42 & 12.12 & 1.67 & 13.79 \\
\hline RH2-1 & 20 & 0.6 & 11.5 & 2.2 & 13.7 \\
\hline RH2-2 & 20 & 0.5 & 12.7 & 1.05 & 13.75 \\
\hline RH2-3 & 20 & 1.1 & 11.05 & 2.4 & 13.45 \\
\hline RH2-4 & 20 & 0.5 & 11.65 & 2.1 & 13.75 \\
\hline RH2-5 & 23 & 1.3 & 11.1 & 2.25 & 13.35 \\
\hline RH2-6 & 20 & 2.15 & 11.3 & 2.15 & 13.45 \\
\hline RH2-7 & 31 & 1.7 & 11.11 & 2.05 & 12.97 \\
\hline RH2-8 & 20 & 1.1 & 11.5 & 1.95 & 13.45 \\
\hline RH2-9 & 22 & 1.3 & 11.4 & 1.95 & 13.35 \\
\hline RH2-10 & 20 & 0.7 & 10.6 & 2.35 & 12.95 \\
\hline RH2-11 & 24 & 3.45 & 11.25 & 2.05 & 13.3 \\
\hline RH2-12 & 20 & 0.5 & 12.25 & 1.45 & 13.7 \\
\hline
\end{tabular}




\begin{tabular}{|c|c|c|c|c|c|}
\hline Species and hybrids & No. of cells observed & Chromosome pairing & Chromosome pairing & Chromosome pairing & Chrom \\
\hline RH2-13 & 20 & 0.9 & 11.2 & 2.35 & 13.55 \\
\hline RH2-14 & 20 & 0.85 & 11.2 & 2.45 & 13.65 \\
\hline RH2-15 & 20 & 2.1 & 10.6 & 2.35 & 12.95 \\
\hline RH2-16 & 20 & 0.5 & 10.95 & 2.8 & 13.75 \\
\hline RH2-17 & 20 & 0.95 & 10.7 & 2.85 & 13.55 \\
\hline RH2-18 & 20 & 0.7 & 11.6 & 2.05 & 13.65 \\
\hline RH2-19 & 20 & 1.2 & 12.2 & 1.2 & 13.4 \\
\hline RH2-20 & 20 & 0.1 & 11.5 & 2.45 & 13.95 \\
\hline RH2-21 & 19 & 0.42 & 11.32 & 2.21 & 13.53 \\
\hline RH2-22 & 47 & 0.46 & 12.66 & 1.07 & 13.73 \\
\hline RH2-23 & 20 & 0.2 & 11.75 & 2.15 & 13.9 \\
\hline RH2-24 & 20 & 0.4 & 11.45 & 2.35 & 13.8 \\
\hline RH2-25 & 27 & 0.2 & 12 & 1.9 & 13.9 \\
\hline RH2-26 & 35 & 0.6 & 11.85 & 1.85 & 13.7 \\
\hline RH2-27 & 21 & 0.5 & 11.95 & 1.8 & 13.75 \\
\hline RH2-28 & 24 & 1 & 11.95 & 1.55 & 13.5 \\
\hline RH2-29 & 22 & 0.8 & 11.65 & 2.05 & 13.7 \\
\hline RH2-30 & 26 & 0.4 & 11.8 & 2 & 13.8 \\
\hline RH2-31 & 31 & 0 & 11.55 & 2.45 & 14 \\
\hline RH2-32 & 38 & 0.68 & 11.82 & 1.87 & 13.69 \\
\hline RH2-33 & 37 & 0.7 & 11.81 & 1,81 & 13.62 \\
\hline RH2-34 & 24 & 0.8 & 11.35 & 2.25 & 13.6 \\
\hline RH2-35 & 24 & 0.5 & 11.69 & 1.98 & 13.67 \\
\hline RH2-36 & 40 & 1.2 & 11.65 & 1.75 & 13.4 \\
\hline RH2-37 & 23 & 0.8 & 12.65 & 0.85 & 13.5 \\
\hline RH2-38 & 19 & 1.48 & 11.32 & 1.92 & 13.24 \\
\hline RH2-39 & 48 & 0.58 & 11.81 & 2.1 & 13.91 \\
\hline RH2-40 & 39 & 0.1 & 12.21 & 1.72 & 13.93 \\
\hline
\end{tabular}




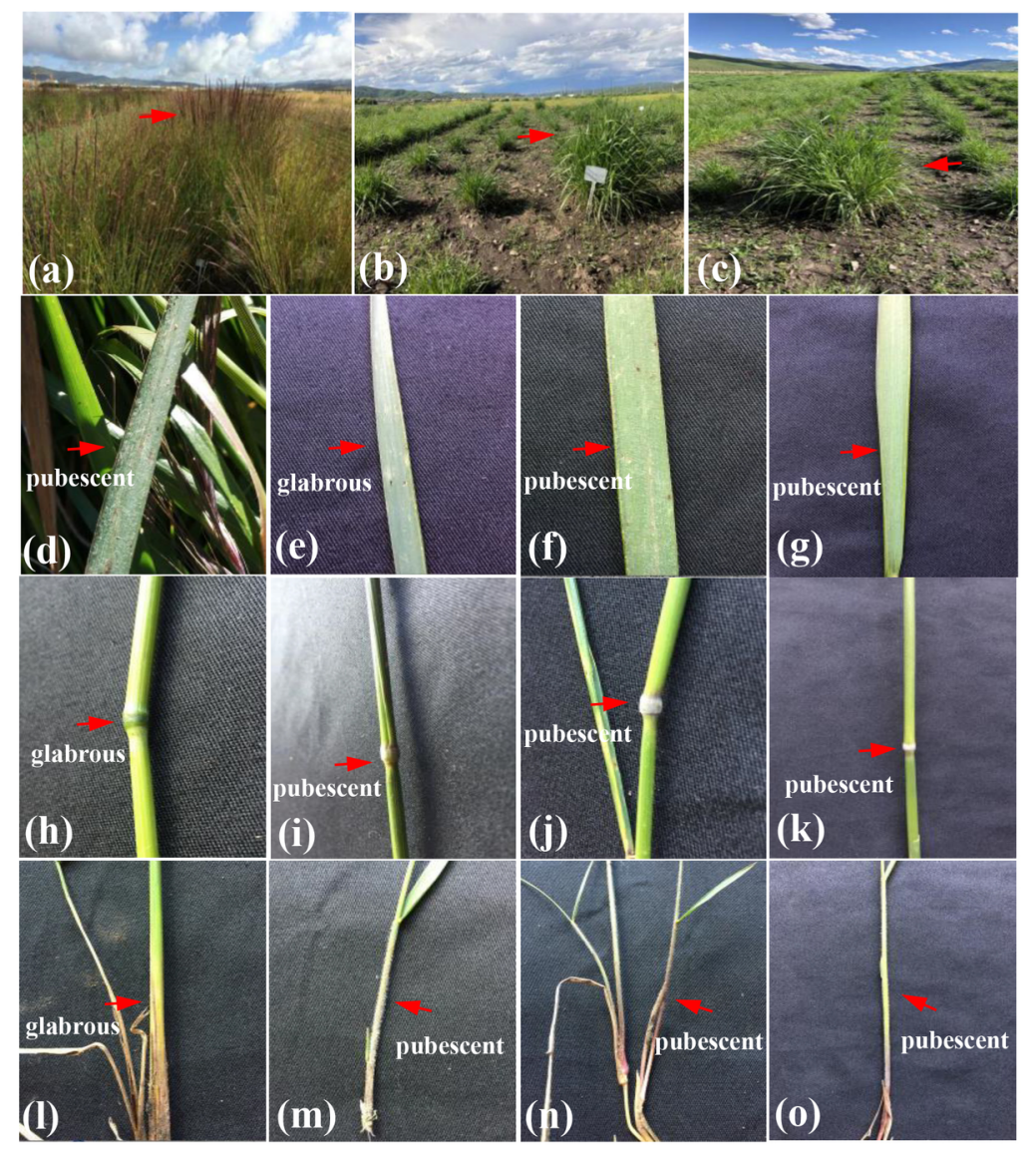



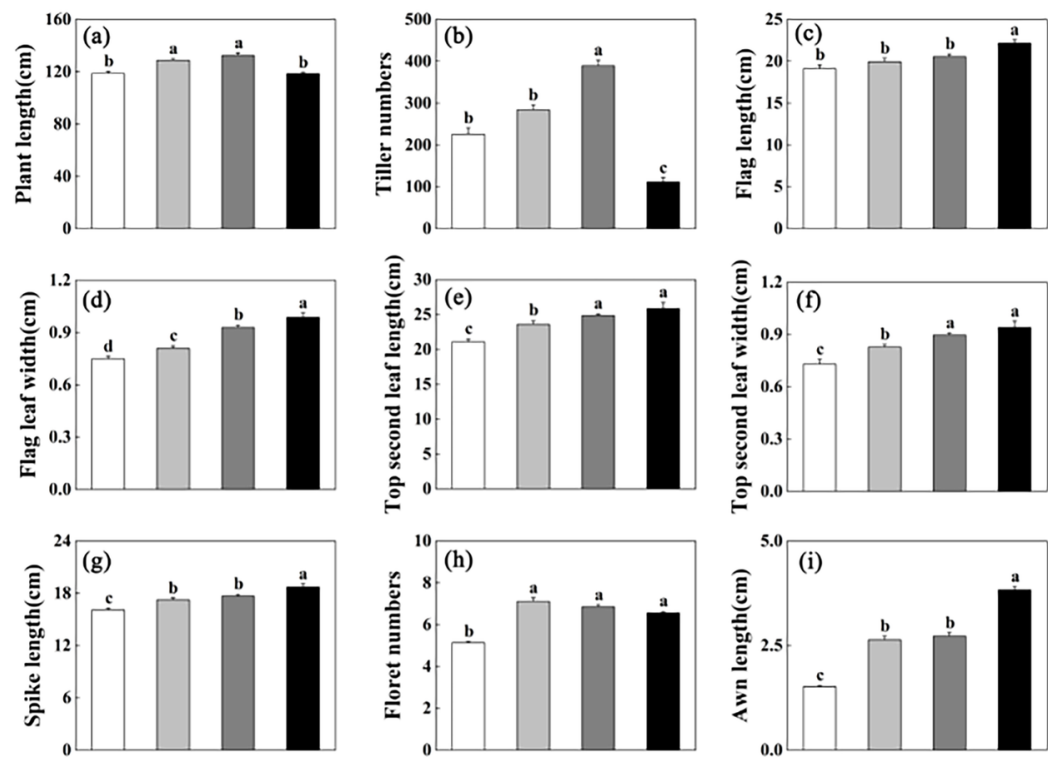

$\square$ R.stricta $\square$ Hybrid RH1 $\square$ Hybrid RH2 $\square$ R.turczaninovii

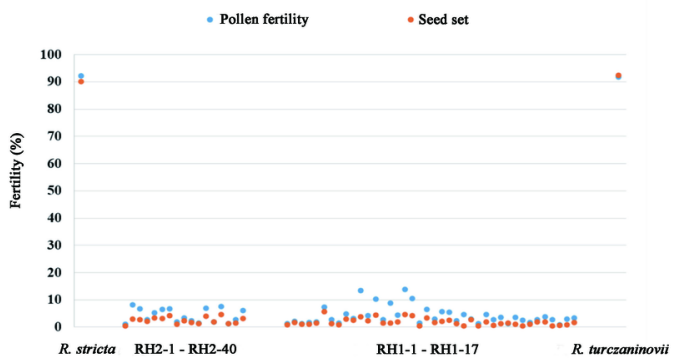




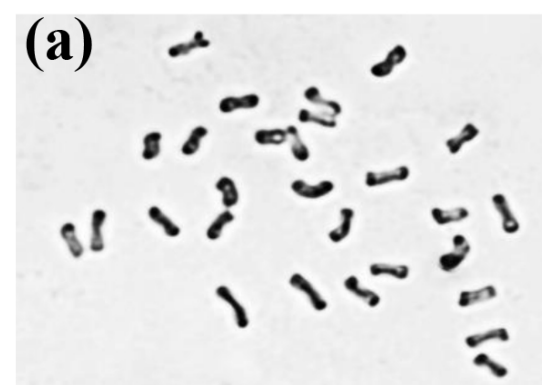

(c)

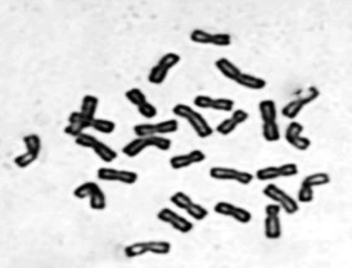

(b)

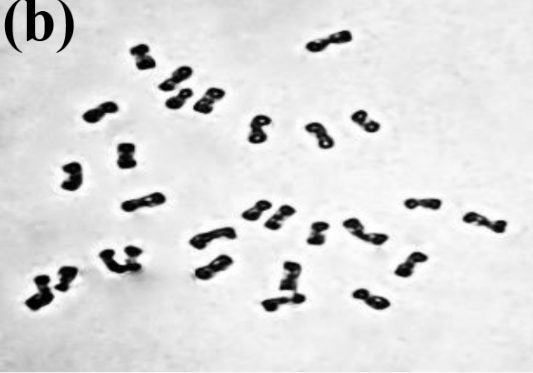

(d)

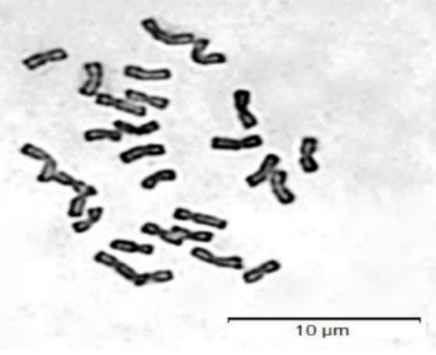

(a)

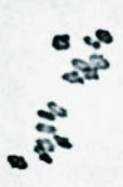

(d)

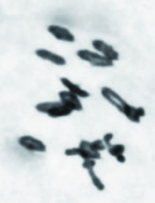

(g)

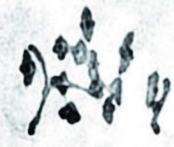

(b)

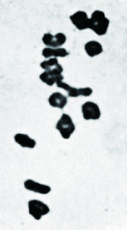

(e)

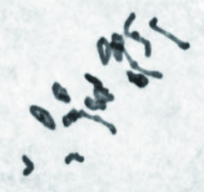

(h)

1. (c)

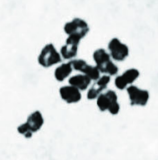

(f)

45

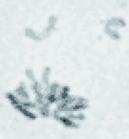

(i)

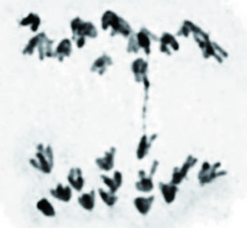




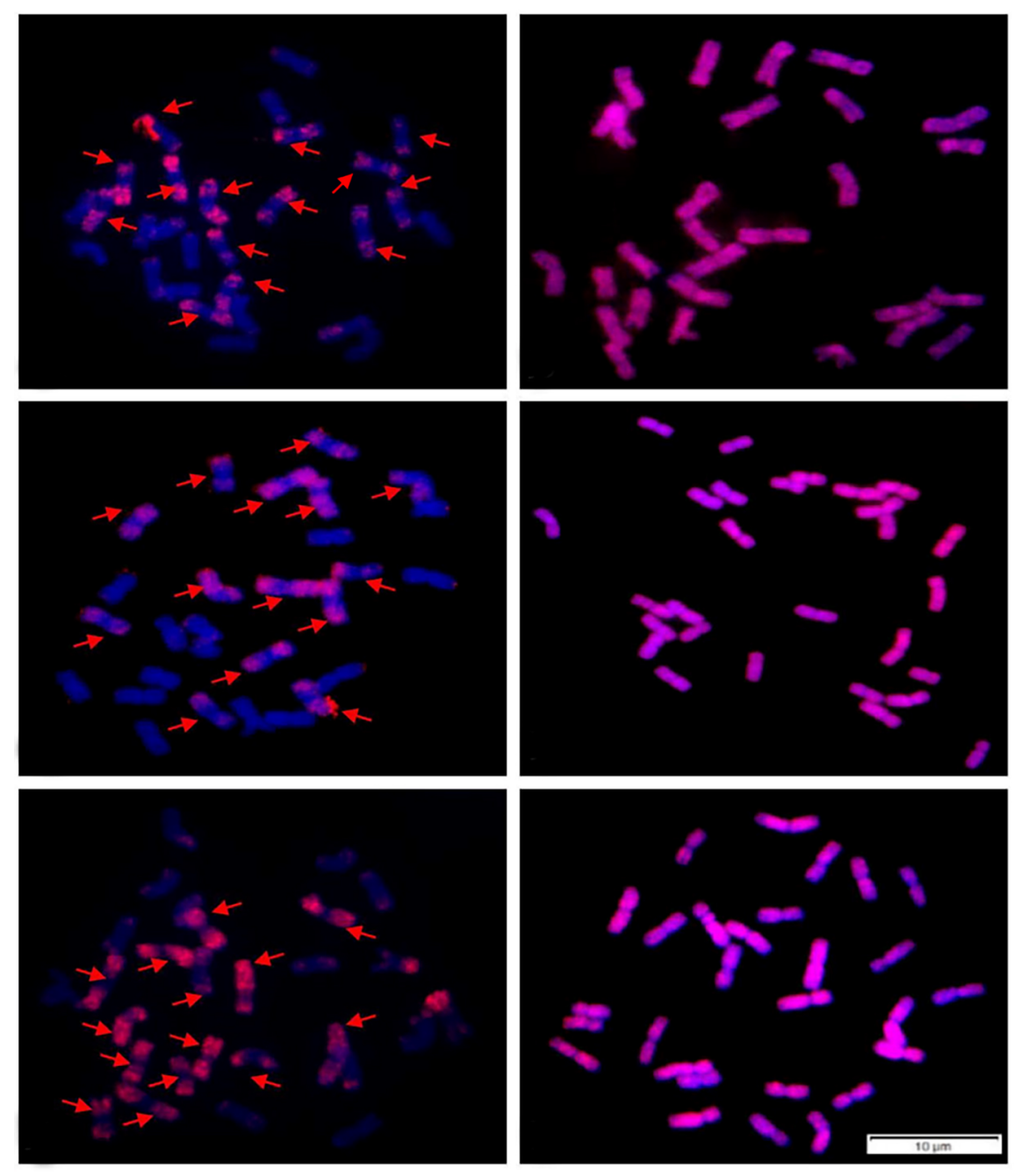



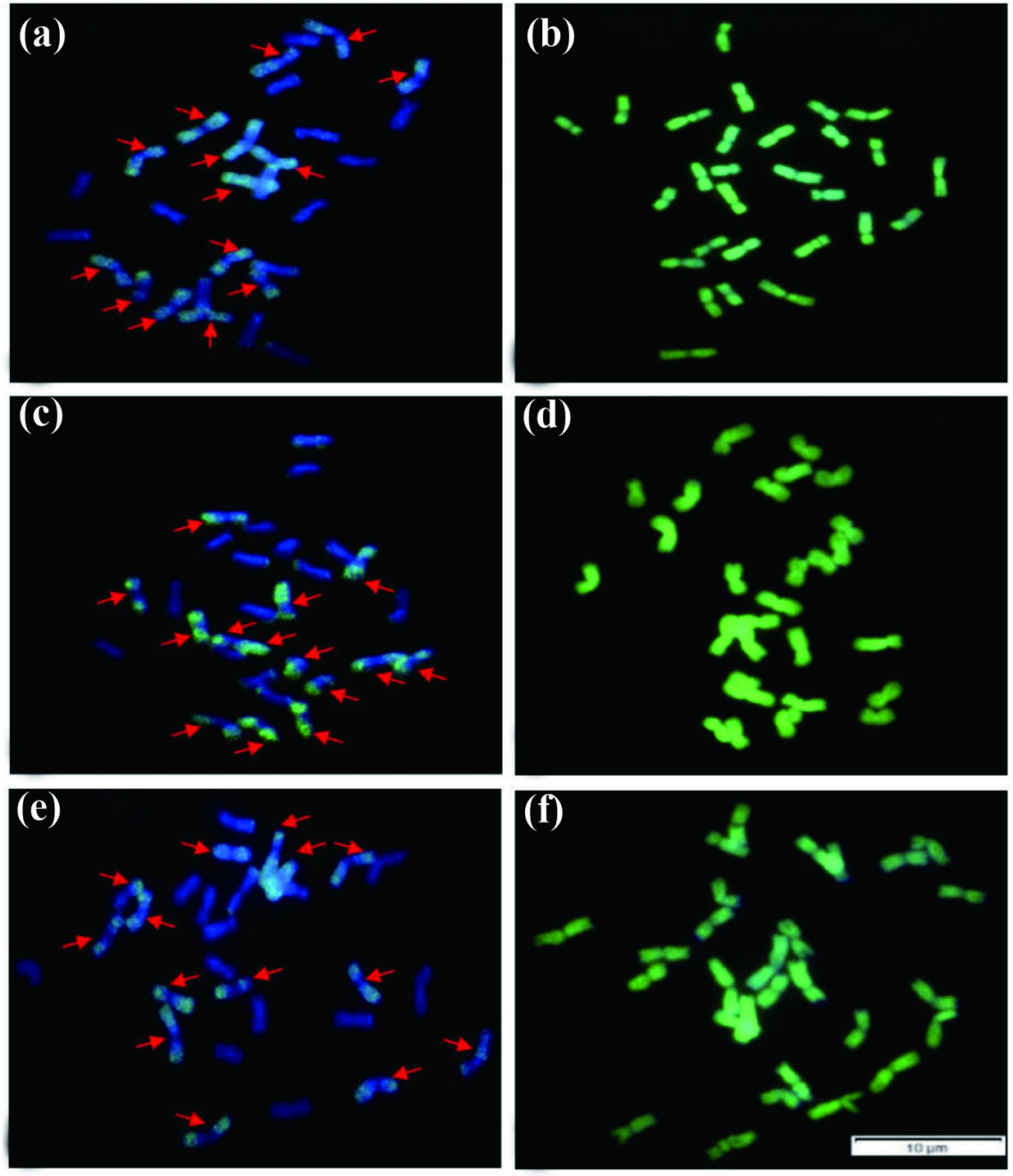


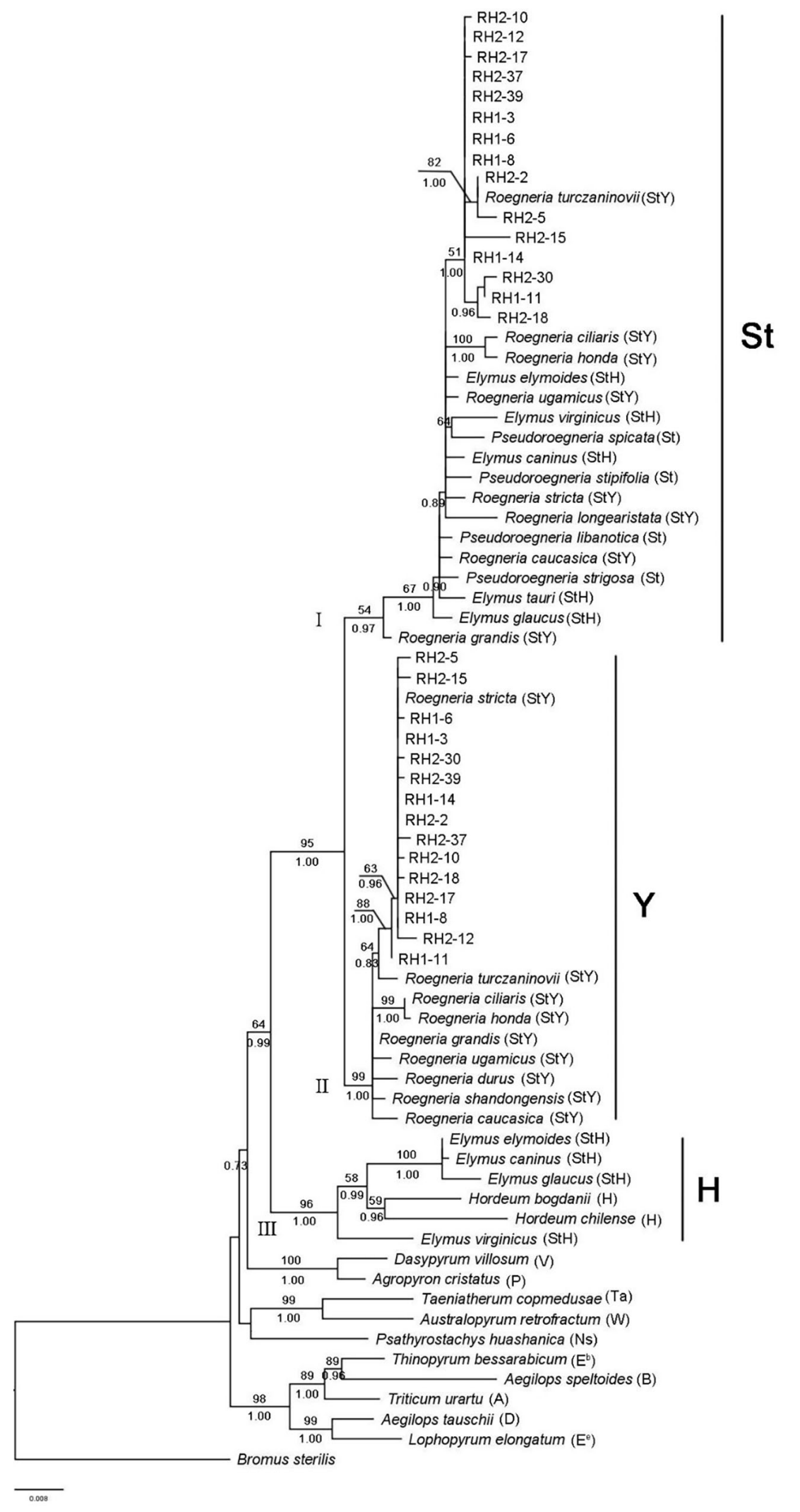




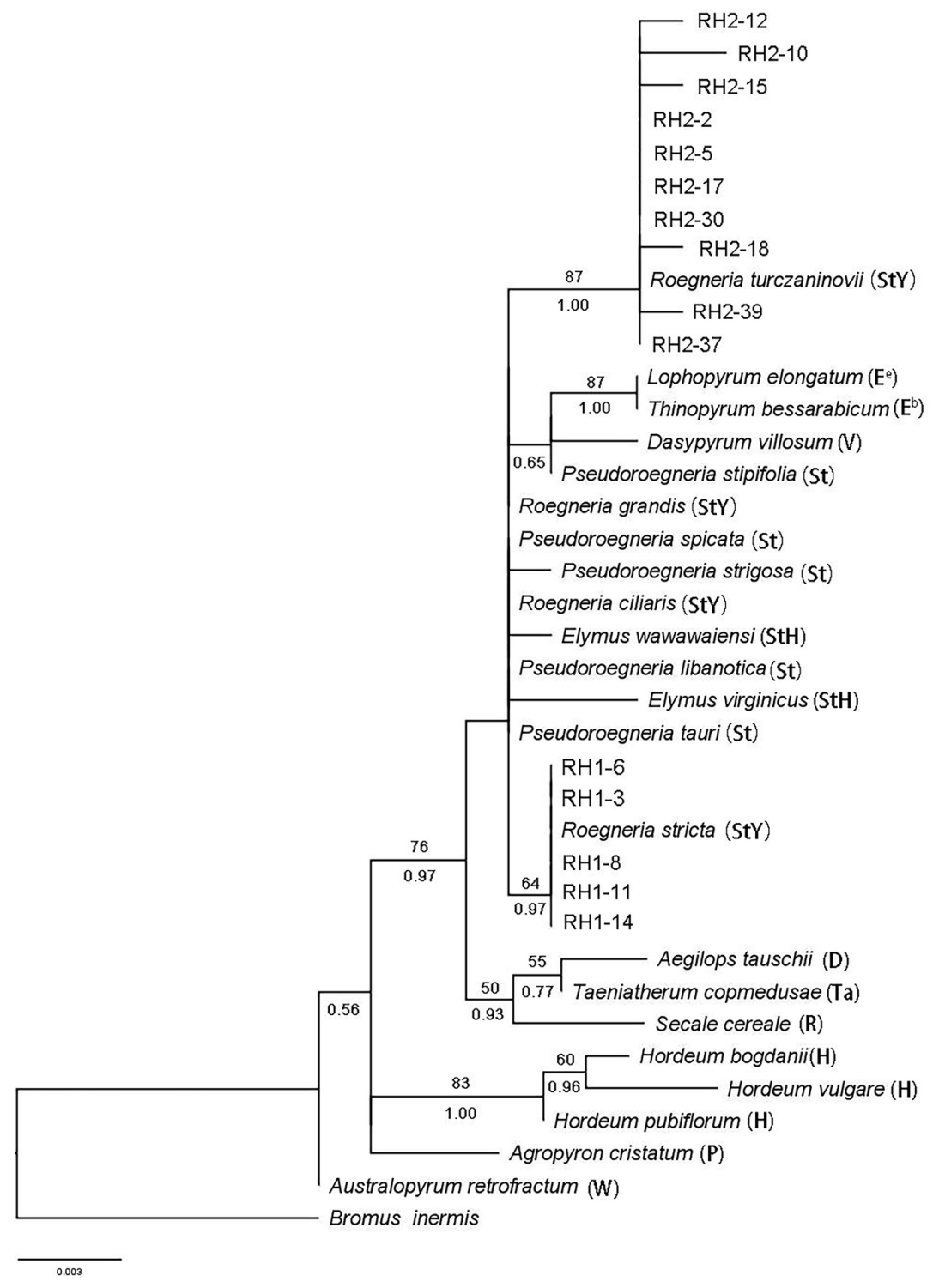

